\title{
Mineral chemistry, petrology and geochemistry of the Sebago granite-pegmatite system, southern Maine, USA
}

\author{
Michael A. WISE*, Cathleen D. BROWN \\ Department of Mineral Sciences, National Museum of Natural History, Smithsonian Institution, Washington, D.C., 20560, U.S.A; \\ wisem@si.edu \\ ${ }^{*}$ Corresponding author
}

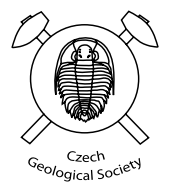

The Permian (293 \pm 2 Ma) Sebago Pluton is a homogeneous, two-mica granite situated in the Oxford pegmatite field, southwestern Maine. Surrounding the pluton is an area designated as the Sebago Migmatite Domain (SMD) dominated by metapelitic migmatites and diatexites with subordinate intrusions of heterogeneous, two-mica and biotite granites, pegmatitic leucogranites and granitic pegmatites. The Sebago Pluton plus the SMD formerly defined the extent of the Sebago Batholith. Most of the granitic pegmatites and bodies of pegmatitic leucogranites occur either within, or barely outside, the margins of the SMD. The pegmatitic leucogranite facies displays units typical of fertile granites (granites that produce granitic pegmatites) and include: megacrystic graphic K-feldspar, sodic aplite and potassic pegmatite pods hosting rare tourmaline, beryl and columbite-tantalite. Over 100 granitic pegmatite bodies (Sebago Pegmatite Group - SPG) intrude the outer portions of the SMD and neighboring granitoids and metasedimentary rocks. The pegmatite population includes mineralogically simple to complexly zoned pegmatites that are characterized by a LCT-type (Li, Cs and Ta) geochemical signature, extensive replacement of primary zones and gem-bearing miarolitic cavities.

Sebago granites are strongly peraluminous and show rare-element enrichment typical of evolved fertile granites $(\mathrm{K} / \mathrm{Rb}=87-257), \mathrm{Rb} / \mathrm{Tl}=10.6-71.3, \mathrm{Ba} / \mathrm{Rb}=0.18-5.04, \mathrm{Al} / \mathrm{Ga}=1419-1749, \mathrm{Zr} / \mathrm{Sn}=1.53-43.9)$. The SPG shows high levels of $\mathrm{Be}, \mathrm{Nb}>\mathrm{Ta}, \mathrm{P}, \mathrm{Li}$ and $\mathrm{B}$ with subordinate enrichment in $\mathrm{Rb}$ and $\mathrm{Cs}$. Moderate to high levels of rare-element fractionation are encountered in pegmatitic $\mathrm{K}$-feldspar $(\mathrm{K} / \mathrm{Rb} \approx 17, \mathrm{~K} / \mathrm{Cs} \approx 90, \mathrm{Rb} / \mathrm{Tl} \approx 75)$, muscovite $(\mathrm{K} / \mathrm{Rb} \approx 6.6$, $\mathrm{K} / \mathrm{Cs} \approx 14.8, \mathrm{Rb} / \mathrm{Tl} \approx 127)$, beryl $\left(\mathrm{Na} / \mathrm{Li} \approx 1.77, \mathrm{Cs}_{2} \mathrm{O} \approx 3.15\right.$ wt. \%), garnet $[\mathrm{Mn} /(\mathrm{Mn}+\mathrm{Fe}) \approx 0.60]$, manganotantalite and ixiolite/wodginite $[\mathrm{Mn} / \mathrm{Mn}+\mathrm{Fe}) \approx 0.98, \mathrm{Ta} /(\mathrm{Ta}+\mathrm{Nb}) \approx 0.80-0.93]$.

Evidence that supports the pegmatitic leucogranites as the likely parent to the SPG includes the close spatial distribution of the pegmatites to the leucogranite bodies, texturally and mineralogically similar units observed within the leucogranite and the neighboring pegmatites plus gradual, yet overlapping, rare-element fractionation from the leucogranites to the associated pegmatites. A few pegmatites (e.g., the Lord Hill pegmatite and amethyst-bearing pegmatites) show NYF tendencies unlike any other pegmatites of the SPG. Differences in fractionation degree, evolution and/or relation to another fertile granite-pegmatite system may be responsible for this apparently anomalous group of pegmatite dikes.

Keywords: granite-pegmatite system, mineral chemistry, petrology, geochemistry, Sebago, southern Maine Received: 1 October 2009; accepted: 30 March 2010; handling editor: M. Novák

\section{Introduction}

The granitic pegmatites of southern Maine represent one of several major pegmatite regions within the Appalachian Province of the eastern United States. Widespread gemological and scientific interest in the granitic pegmatites of the Sebago area was stimulated by the discovery of gem-grade tourmaline at the Mt. Mica pegmatite in 1820 and subsequent feldspar and mica mining in the region. Unfortunately, very little geochemical data exist for the Maine pegmatites despite their popularity among mineral collectors and geoscientists. Most of the studies on Maine pegmatites were largely descriptive with an emphasis on characterizing their mineralogy (e.g., Bastin 1911; Landes 1925; Woodard 1951; Francis et al. 1991). The works of Cameron et al. (1954) and Barton and Goldsmith (1968) identified the general internal zona- tion of many Maine pegmatites enriched in the strategic metals $\mathrm{Be}, \mathrm{Nb}, \mathrm{Ta}$ and $\mathrm{Li}$, but did not discuss the crystallization history or chemical evolution of the individual pegmatites. With few exceptions (e.g. Simmons et al. 1995; Wise 1995; Simmons et al. 2005), details on the mineral chemistry of pegmatites in the Sebago area are inadequate. Of the nearly 120 known pegmatite deposits in the Sebago area (Rand 1957; Thompson et al. 2000) only two (Lord Hill - Johnson 1998; Bennett - Wise and Rose 2000) have been studied sufficiently enough to characterize their geochemical evolution and crystallization history.

Several studies have addressed the petrogenesis of the Sebago granite (Hayward 1989; Tomascak et al. 1996a, b; Dorais and Paige 2000) considered by some to be the parental granite of the pegmatite population (e.g., Wise and Francis 1992). Although Guidotti et al. (1986) and 
Wise and Francis (1992) suggested a cogenetic relationship among the pegmatites of the Sebago area, their claim is unsupported by geochemical, geochronological or isotopic data which would aid in evaluating potential links between granites and groups of diverse pegmatites even though physical transitions may not exist (e.g., Shearer et al. 1987). A rigorous investigation addressing the rare-element enrichment of the pegmatite population and their possible genetic connections to neighboring granitic intrusions (e.g., Sebago and Songo plutons) is not yet available.

Given the importance of granitic pegmatites to the gem mining industry in western Maine, it is essential that the mineralogy and chemical evolution of these deposits is understood if guidelines for future exploration are to be developed. This study employs new chemical data obtained from the Sebago granite and its nearby pegmatite population in an attempt to characterize the patterns of rare-element enrichment of the pegmatites and to provide a foundation for assessing their petrogenetic relationship with the Sebago granite.

\section{General regional geological setting}

Granitic pegmatites are widespread throughout southern Maine and the largest percentage is found adjacent to the Sebago granite in the southern portion of the Oxford pegmatite field (Figs 1-2; Wise and Francis 1992). The Oxford pegmatite field is underlain by rocks of the Central Maine Belt (CMB), a prominent NE-SW trending unit that extends from Connecticut to New Brunswick, Canada and occupies much of southern Maine. The CMB consists of deformed and metamorphosed Lower Paleozoic sedimentary rocks that experienced greenschist to upper amphibolite facies metamorphic conditions during the Acadian Orogeny (Solar and Brown 2001 and references therein). The resulting migmatite domains consist of stromatic migmatites, diatexites and schlieren granites. The CMB is intruded by Devonian to Permian age peraluminous granite, quartz monzonite, and granodiorite plutons which may have contributed to local deformation and contact metamorphism of the surrounding rocks. The granitoids range in composition from titanite-bearing granodiorites (e.g. Songo Pluton) to biotite-muscovite granites, some displaying the local development of a pegmatitic facies (e.g. Rumford Pluton). Pegmatites associated with the late Paleozoic plutonism are presently concentrated interior and marginal to the granitic plutons.

The dominant igneous intrusion in the southern portion of the Oxford pegmatite field is the Sebago Pluton (formerly the Sebago Batholith). Previous studies showed the Sebago Pluton as a single large plutonic body with

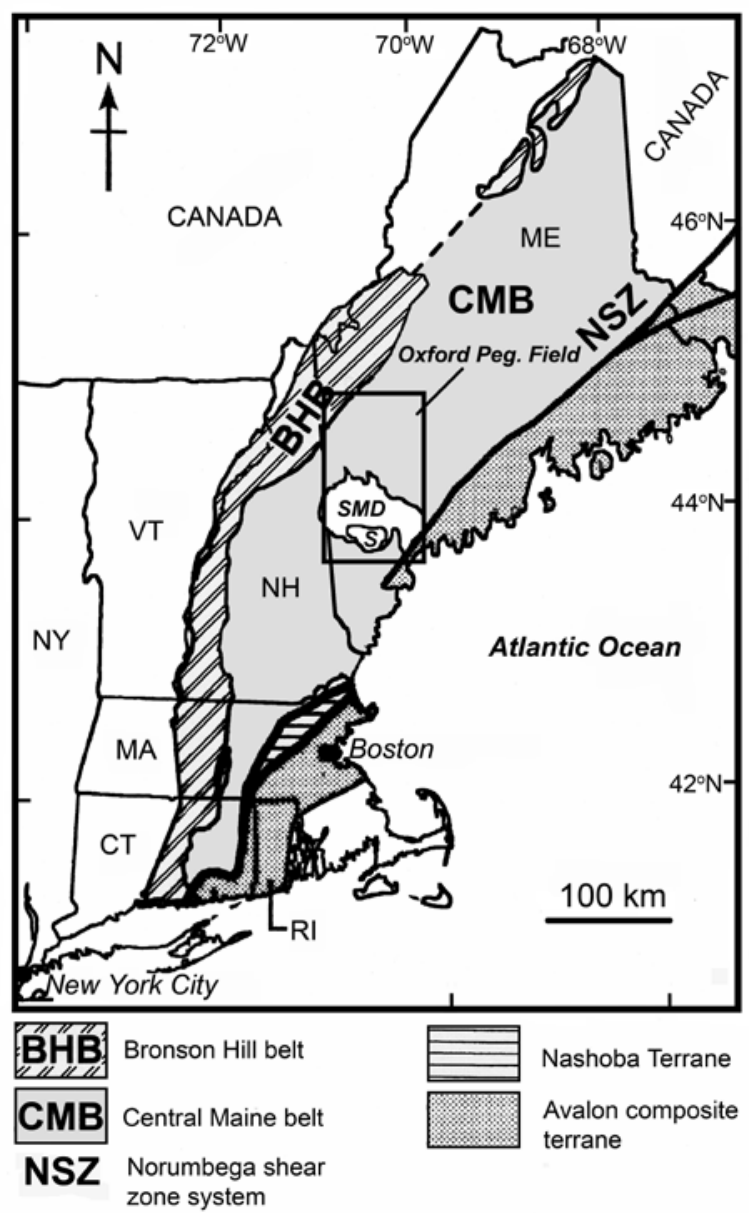

Fig. 1 Map of New England region showing the location of the Sebago Pluton (S) and Sebago Migmatite Domain (SMD) within the Oxford pegmatite field (rectangle). ME - Maine, NH - New Hampshire, VT - Vermont, NY - New York, MA - Massachusetts, CT - Connecticut, RI - Rhode Island. Map modified after Brown and Solar (1998).

an areal extent of approximately $\sim 2,700 \mathrm{~km}^{2}$ (Osberg et al. 1985). However, recent work by Solar and Tomascak (2009), describes the Sebago Pluton $(293 \pm 2 \mathrm{Ma}$; Tomascak et al. 1996a) as a $400 \mathrm{~km}^{2}$ granitic body surrounded by an envelope of migmatitic rocks referred to as the Sebago Migmatite Domain (SMD) (Fig. 2). They relegate the "true" Sebago Pluton to the southern portion of the former extent of the Sebago Batholith described by Osberg et al. (1985). According to Solar and Tomascak (2009), the Sebago Pluton is composed of two-mica granite that is both texturally and chemically homogenous. The SMD consists of metapelitic migmatite and diatexite that is intruded by smaller, texturally heterogeneous granite sheets, schlieren granites and pegmatite dikes.

Geophysical studies suggested that the Sebago granite is a thin sheet-like body approximately $0.5-2 \mathrm{~km}$ thick (Hodge et al. 1982) that dips about 3 degrees to the northeast (Carnese 1983). However, a later study by Behn et 


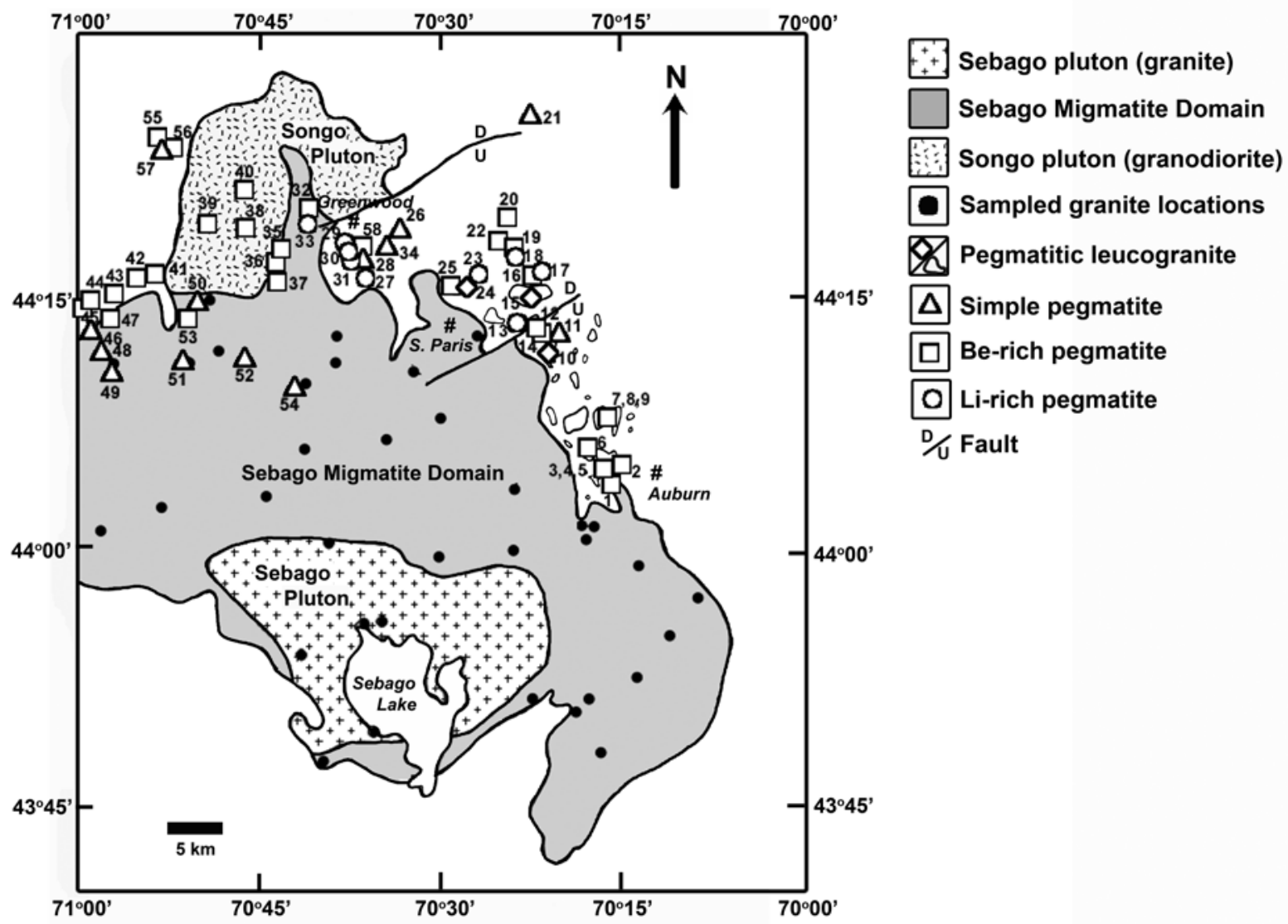

Fig. 2 Generalized geologic map of the southern portion of the Oxford pegmatite field. Note the relationship between the Sebago Pluton and Sebago Migmatite Domain of Solar and Tomascak (2009) to the adjacent Sebago Pegmatite Group. See Tab. 1 for key to numbered pegmatite locations.

al. (1998) indicates that both the northern and southern margins of the pluton dip shallowly beneath the cover of the metasedimentary rocks to form an arched body. Estimates of metamorphic pressures of the rocks immediately north of the pluton range from 3.3 to 3.8 kbars (Holdaway et al. 1988; Thomson and Guidotti 1989) suggesting emplacement depths of about 10-14 km.

\section{Sebago granite-pegmatite System}

\subsection{Granites of the Sebago Pluton and Sebago Migmatite Domain}

Tomascak et al. (1996b) and Solar and Tomascak (2001, 2009) divided the granite of the former Sebago Batholith into two groups based on geochemical, textural and isotopic data. The group 1 granites (Sebago Pluton sensu stricto) consist of fine- to medium-grained, homogeneous two-mica granites. They have $\varepsilon_{\mathrm{Nd}}$ values of -3.5 to -1.5 . By comparison, group 2 granites (SMD granites) are texturally and chemically heterogeneous, two-mica granites associated with enclaves and schlieren that intruded the SMD as dikes to small, isolated bodies. They have $\varepsilon_{\mathrm{Nd}}$ values that range from -6.0 to -3.0 . Biotite granites in the SMD have $\varepsilon_{\mathrm{Nd}}$ values of -4.6 to -3.8 .

Along the outer margins of the SMD we observed several small satellite stocks (originally mapped by Creasy 1979) that exhibit textural features similar to those described by Černý and Meintzer (1988) for fertile granites parental to mineralized pegmatite populations. Specifically, the pegmatitic leucogranite facies of Černý and Meintzer (1988) have been identified at several places, most notably at Streaked Mountain. The pegmatitic leucogranite consists of coarse, blocky, graphic $\mathrm{K}$-feldspar megacrysts surrounded by a medium-grained matrix of quartz, plagioclase and muscovite with accessory tourmaline and minor garnet and fluorapatite (Fig. 3). Locally, this facies grades into pegmatite pods consisting of blocky perthitic K-feldspar, quartz, muscovite with accessory tourmaline and garnet. Beryl and rare ferrocolumbite are locally present. An albitic aplite facies comprised of fine-grained albite, quartz and accessory garnet and tourmaline occurs as isolated blocks or 

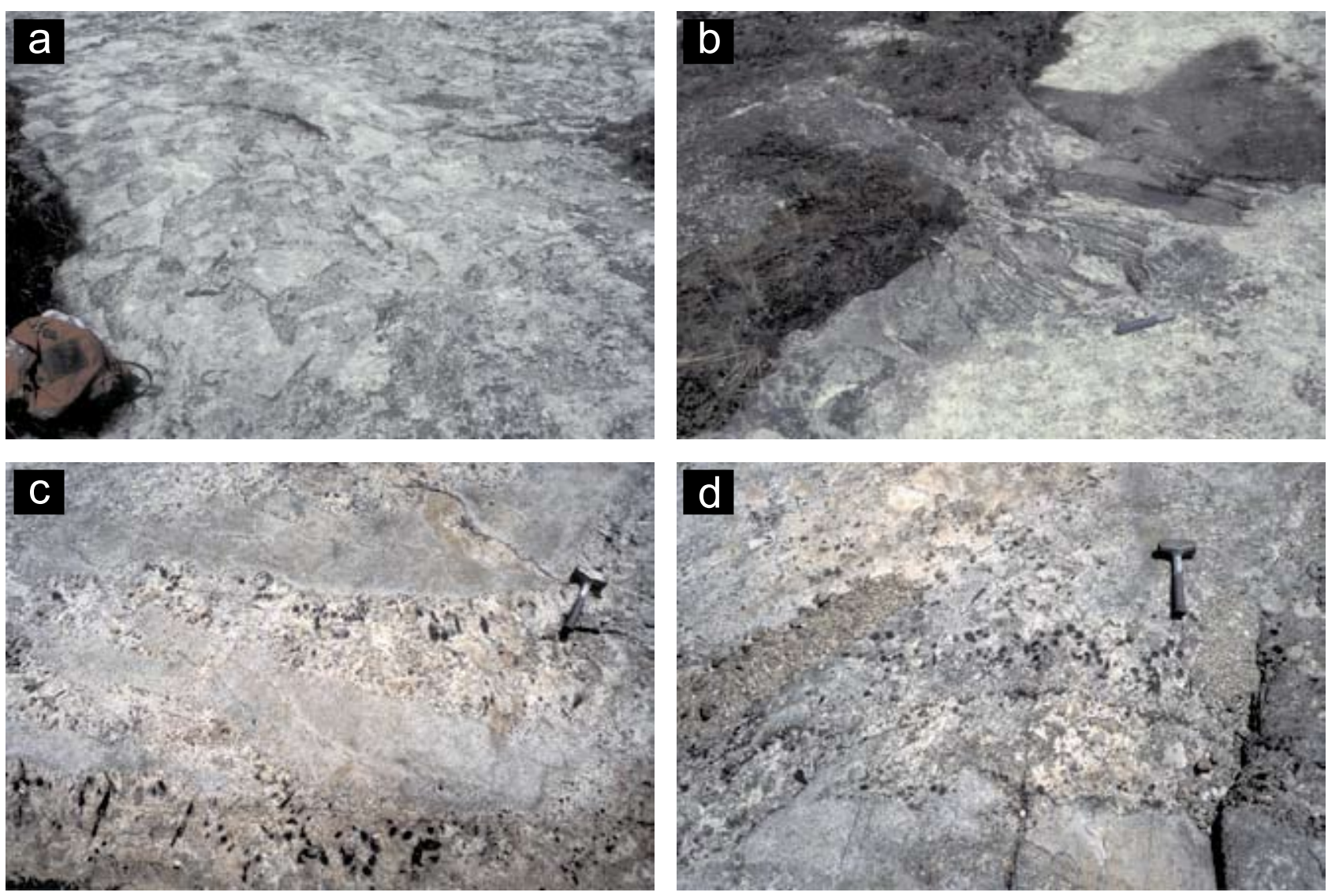

Fig. 3 Textural facies of pegmatitic leucogranites of the Sebago area. a - Light-colored megacrystic graphic K-feldspar in a darker matrix of medium-grained quartz, plagioclase and muscovite groundmass - Streaked Mountain. b - Raft of country-rock schist in megacrystic graphic K-feldspar facies - Streaked Mountain. c - Pavement outcrop showing interlayering of simple pegmatite veins and aplite - near Auburn. d - Pavement outcrop showing simple pegmatite vein with bands of almandine garnet along the upper and lower contacts with aplite and megacrystic K-feldspar facies - near Auburn.

interlayered with pegmatite veins within the pegmatitic leucogranite (Fig. 3). Xenoliths of schist are common in the pegmatitic leucogranites (Fig. 3b).

\subsection{Distribution and classification of the Sebago Pegmatite Group (SPG)}

Wise and Francis (1992) summarized the distribution of pegmatites surrounding the Sebago Pluton - SMD (formerly Sebago Batholith) and showed that the pegmatite population, henceforth referred to as the Sebago Pegmatite Group (SPG), consisted of spatially related clusters of mineralogically and texturally diverse pegmatites (Fig. 2). The pegmatites in the Sebago area fit into the classification of LCT family of rare-element granitic pegmatites, as described by Černý (1991) and Černý and Ercit (2005). In general, three categories of pegmatites distinguished by mineral assemblage and geochemistry have been recognized in the SPG (Tab. 1): (1) quasi-homogeneous, simple pegmatites, (2) beryl \pm columbite \pm phosphate-bearing and (3) complex Li-enriched pegmatites (spodumene and petalite subtypes). Miarolitic cavities hosting gem quality minerals are uncommon in most of the SPG and are best developed in the Li-enriched pegmatites.

Simple pegmatites are hosted mainly by the SMD and consist of perthitic K-feldspar, albite, quartz, muscovite and biotite. The internal zoning may be absent, or at best, poorly developed. K-feldspar crystals typically exhibit graphic textures, although small amounts of non-graphic, blocky K-feldspar may also occur. Quartz is ubiquitous, rarely forming well-developed pods or lenses. Isolated patches of rose quartz are rarely found at some localities. Albite typically occurs as anhedral interstitial grains and rarely as blocky crystals. Mica species are represented by biotite and muscovite. When present, biotite occurs as $\mathrm{mm}$-size flakes to elongated blades several $\mathrm{cm}$ in length. In some cases, biotite books may be intergrown with, or overgrown by, muscovite. Muscovite is generally intergrown with quartz, but occurs as discrete crystals near the margins of quartz-rich pods. Black tourmaline (schorl-dravite) and almandine-rich garnet are common accessory minerals; in some pegmatites, fluorapatite may be locally abundant. 
Tab. 1 Representative examples of rare-element pegmatites within the Sebago Group

\begin{tabular}{|c|c|c|c|c|c|c|}
\hline Pegmatites & Subtype & Spodumene & Elbaite & Li-micas & Pollucite & Other noteworthy minerals \\
\hline \multicolumn{7}{|l|}{ Simple pegmatites } \\
\hline $26-$ A.C. Perham & SIM & & & & & \\
\hline 57 - Anderson & SIM & & & & & \\
\hline 52 - Burnell Hill & SIM & & & & & \\
\hline 46 - Colton Hill & SIM & & & & & Amethyst \\
\hline 11 - Conant & SIM & & & & & \\
\hline 49 - Creeper Hill & SIM & & & & & \\
\hline 50 - Foster Hill & SIM & & & & & \\
\hline $28-$ Nubble & SIM & & & & & Trace chrysoberyl \\
\hline 21 - Ragged Jack Mountain & SIM & & & & & Minor chrysoberyl \\
\hline 51 - Sabbatus Mountain & SIM & & & & & \\
\hline $8-$ Sahib & SIM & & & & & \\
\hline 10 - Streaked Mountain & SIM & & & & & Trace beryl \\
\hline 54 - South Waterford & SIM & & & & & \\
\hline $10-$ Sturtevant & SIM & & & & & \\
\hline 48 - Wiley Mountain & SIM & & & & & Amethyst \\
\hline 34 - Witt Hill & SIM & & & & & Minor chrysoberyl, gahnite \\
\hline \multicolumn{7}{|l|}{ Be-rich pegmatites } \\
\hline $22-$ Bessey & BYL & & & & & \\
\hline 4 - Butler Hill & BYL & & & & & \\
\hline 44 - Deer Hill & BYL & & & & & Amethyst \\
\hline 45 - Eastman Prospects & BYL & & & & & Amethyst \\
\hline 53 - Forks Farm & BYL & & & & & \\
\hline 9 - Green & BYL & & & & & \\
\hline 35 - Guy Johnson & BYL & & & & & \\
\hline 7 - LaFlamme & BYL & & & & & \\
\hline $42-$ Melrose & BYL & & & & & \\
\hline 55 - Peaked Hill & BYL & & & & & \\
\hline 6 - Pitts Tenney & BYL & & & & & \\
\hline 36 - Scribner & BYL & & & & & \\
\hline 32 - Tiger Bill & BYL & & & $(\mathrm{x})$ & $(\mathrm{x})$ & \\
\hline 37 - Wardwell & BYL & & & & & \\
\hline 56 - Wheeler & BYL & & & & & \\
\hline 25 - Whispering Pines & BYL & & & & & \\
\hline $41-$ Willis Warren & BYL & & & & & \\
\hline 43 - Cole & $\mathrm{BC}$ & & & & & \\
\hline $16-\mathrm{GE}$ & $\mathrm{BC}$ & & $X$ & & $\mathrm{X}$ & \\
\hline 2 - Greenlaw & $\mathrm{BC}$ & $(\mathrm{x})$ & $X$ & $\mathrm{X}$ & & \\
\hline $58-$ Heikkinen & $\mathrm{BC}$ & & & & & \\
\hline $14-$ Hibbs & $\mathrm{BC}$ & & & & & \\
\hline 20 - Norman Jack & $\mathrm{BC}$ & & & & & \\
\hline 19 - Orchard Pit & $\mathrm{BC}$ & & $(\mathrm{x})$ & & & \\
\hline 39 - Pingree & $\mathrm{BC}$ & & & & & \\
\hline 24 - Slattery & $\mathrm{BC}$ & & & & & \\
\hline 40 - Songo Pond & $\mathrm{BC}$ & & & & & Rutile \\
\hline 3 - Turner & $\mathrm{BC}$ & & & & & \\
\hline 1 - Berry - Havey & $\mathrm{BCP}$ & $(\mathrm{x})$ & $\mathrm{X}$ & $(\mathrm{x})$ & & Lithiophilite, montebrasite \\
\hline 38 - Bumpus & $\mathrm{BCP}$ & & & & & \\
\hline 47 - Lord Hill & $\mathrm{BCP}$ & & & & & Topaz, triplite \\
\hline 2 - Maine Feldspar & $\mathrm{BCP}$ & $(\mathrm{x})$ & $X$ & $(\mathrm{x})$ & $(\mathrm{x})$ & Gahnite \\
\hline 12 - Mt. Rubellite & $\mathrm{BCP}$ & $(\mathrm{x})$ & $X$ & $\mathrm{X}$ & $(\mathrm{x})$ & Lithiophilite, montebrasite \\
\hline 5 - Pulsifer & $\mathrm{BCP}$ & $(\mathrm{x})$ & $\mathrm{X}$ & $\mathrm{X}$ & $(x)$ & Gahnite, montebrasite \\
\hline \multicolumn{7}{|l|}{ Li-rich pegmatites } \\
\hline $27-\mathrm{BB} \# 7$ & SPD & & $(\mathrm{x})$ & $\mathrm{X}$ & $(\mathrm{x})$ & Cassiterite, lithiophilite \\
\hline 18 - Bennett & SPD & & $\mathrm{X}$ & $X$ & $\mathrm{X}$ & Wodginite, lithiophilite \\
\hline $30-$ Harvard & SPD & & $\mathrm{X}$ & $X$ & $(\mathrm{x})$ & Montebrasite \\
\hline 29 - Hayes & SPD & & & & & \\
\hline 31 - Waisanen & SPD & & $(\mathrm{x})$ & & & Graftonite \\
\hline $33-$ Emmons & PET & $(\mathrm{x})$ & $\mathrm{X}$ & $\mathrm{X}$ & $\mathrm{X}$ & Wodginite, montebrasite \\
\hline 13 - Mt. Marie & PET & (x) & $\mathrm{X}$ & $X$ & $\mathrm{X}$ & \\
\hline 23 - Mt. Mica & PET & (x) & $\mathrm{X}$ & $X$ & $(\mathrm{x})$ & Montebrasite \\
\hline 31 - Tamminen & PET & $(\mathrm{x})$ & $\mathrm{X}$ & $\mathrm{X}$ & $\mathrm{X}$ & Montebrasite \\
\hline $17-$ Westinghouse & PET & & $\mathrm{X}$ & & $\mathrm{X}$ & Chrysoberyl \\
\hline
\end{tabular}

Numbers refer to pegmatite locations in Fig. 2. Pegmatite subtypes: $S I M-$ simple, $B Y L$ - beryl, $B C-$ beryl-columbite, $B C P$ - beryl-columbitephosphate, $S P D$ - spodumene, $P E T$ - petalite. Occurrence: $\mathrm{X}$ - common, $(\mathrm{x})$ - minor. 
The beryl-type pegmatites of the SPG are characterized by Be mineralization accompanied by $\mathrm{Nb}$, Ta mineralization in the beryl-columbite subtype and also by the presence of phosphate minerals (e.g., triphylite-lithiophilite or triplite) in the beryl-columbite-phosphate subtype. Internal zonation of pegmatites of this category ranges from poor to well-developed with micas, tourmaline, and $\mathrm{K}$-feldspar commonly replaced by albite, fine-grained (saccharoidal) and bladed (cleavelandite).

Graphic K-feldspar is present, but the abundance of non-graphic, perthitic K-feldspar is considerably greater than that found in the simple pegmatites. Albite occurs in the same manner as in simple pegmatites; however the bladed variety (cleavelandite) is more common and may occur as isolated lenses or units. Platy muscovite and well-defined quartz or quartz $+\mathrm{K}$-feldspar pods, lenses, or cores are prominent. The quartz is typically white to gray, but rose quartz and amethyst may also occur. Tourmaline (dravite, schorl and foitite), almandine and spessartine garnet, and Mn-bearing fluorapatite are the most common accessory minerals found; rare magnetite, zircon, pyrite, arsenopyrite and pyrrhotite may occur locally.

Beryl is typically pale green in color, although blue varieties are known from a few localities. When present, columbite group minerals vary from ferrocolumbite to manganocolumbite. The number of confirmed berylcolumbite-phosphate subtype pegmatites within the SPG is small, as the overall abundance of Fe-, Mn-, and Li-phosphate minerals is low. Triphylite is abundant in some pegmatites (e.g., BB\#7) and lithiophilite is locally present at the Pulsifer and Emmons pegmatites. Only three pegmatites in the SPG (Pulsifer, Berry-Havey and Lord Hill) are known to contain triplite.

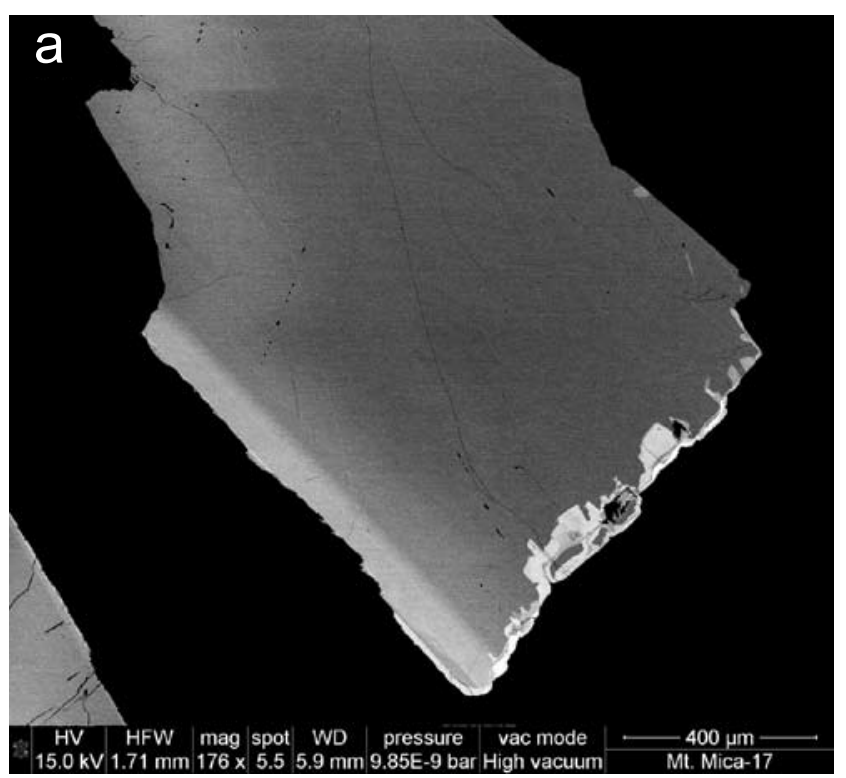

Pegmatites of the complex type are characterized by welldefined internal zonation and replacement textures, diverse mineralogy, and elevated enrichment in rare alkali elements ( $\mathrm{Li}, \mathrm{Rb}, \mathrm{Cs}$ ), high-field strength elements (Nb, Sn, Ta, Zr) and B, P and F. Li-rich pegmatites are found predominantly near the towns of Greenwood and South Paris.

Li-rich pegmatites are primarily of the spodumene-subtype (e.g., Harvard, BB\#7, Hayes, Mt. Mica and Bennett), although petalite-subtype pegmatites (e.g., Mt. Marie, Tamminen, Emmons, Westinghouse) also occur. Blocky, perthitic, non-graphic K-feldspar is abundant, whereas, graphic K-feldspar is subordinate. Pods and lenses of albitic aplite and bladed albite are much more common relative to anhedral and blocky albite crystals. Miarolitic cavities and fractures, if present, may contain copious amounts of cleavelanditic albite. Books of platy muscovite are common, locally grading to pale purple lithium muscovite (3.0 to 4.0 wt. \% $\mathrm{Li}_{2} \mathrm{O}$; Levinson 1953). Although lithium muscovite is relatively widespread, it does not occur in any great abundance, nor is it ever the dominant Li-aluminosilicate in any pegmatite. Biotite occurs rarely in the wall zones of Li-rich pegmatites as small $(\sim 2 \mathrm{~mm}$ long) black flakes. Beryl, columbite group minerals, Mnrich garnet, elbaite and lithian muscovite and/or lepidolite (4.0 to 7.0 wt. \% $\mathrm{Li}_{2} \mathrm{O}$; Levinson 1953) are the most common accessory minerals in these pegmatites. The color of beryl ranges from pale green through blue to colorless, white and pink. Tantalum and tin enrichment is expressed by the crystallization of manganotantalite, ferrotapiolite, wodginite and cassiterite, which sometimes show complex chemical zoning (Fig. 4). Local occurrences of pollucite and amblygonite-montebrasite further emphasize the highly fractionated nature of these pegmatites.

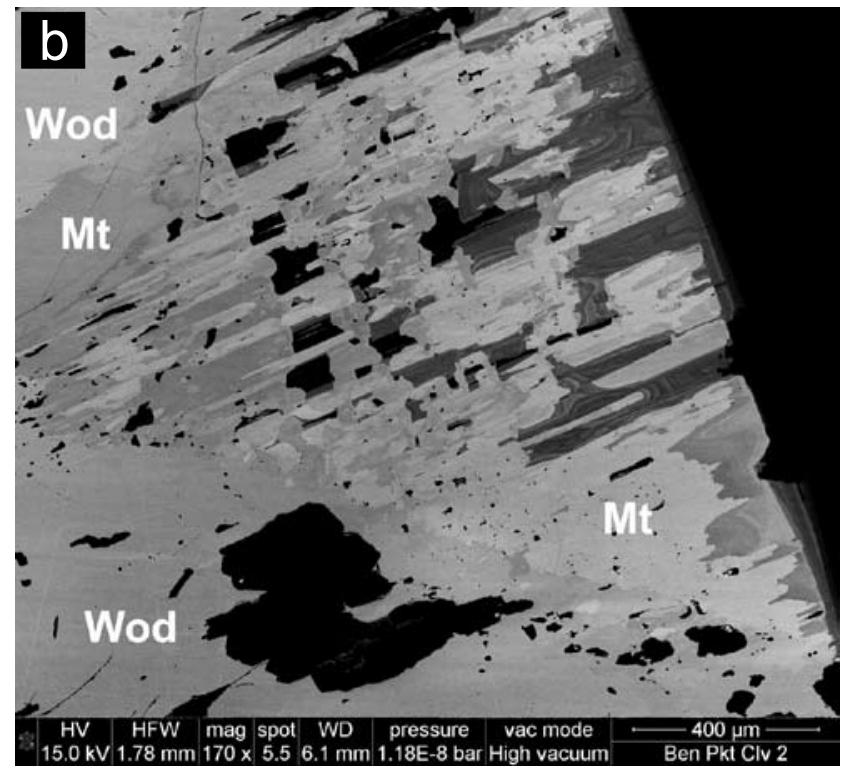

Fig. 4 Back-scattered electron (BSE) images of Nb-Ta oxide minerals from the Sebago pegmatite group. a - Zoned manganocolumbite crystal with minor late-stage irregular zoning (Mt. Mica pegmatite). b - Wodginite (Wod) in association with manganotantalite (Mt) (Bennett pegmatite). Note the irregular zoning patterns of manganotantalite caused by late-magmatic to subsolidus partial dissolution-reprecipitation. 


\section{Whole-rock and mineral chemistry}

\subsection{Analytical techniques}

Fresh granite samples were slabbed, reduced to $0.7 \mathrm{~cm}$ sized pieces, and crushed in a steel jaw-crusher. After the crushed rock was quartered, a representative split was pulverized to a $0.074 \mathrm{~mm}$ powder in an alumina ceramic mill. The powder was analyzed for major and trace elements in our laboratory by X-ray fluorescence (XRF). Rare-earth elements were determined by ICP-MS method by SGS Canada Laboratories.

The following discussion on mineral chemistry is limited to primary phases that are routinely used to characterize the geochemical evolution of granitic pegmatites. $\mathrm{K}$-feldspar and mica-group minerals were collected from the core-margin or cores of zoned pegmatites. In the case of unzoned or poorly zoned pegmatites commonly lacking well-developed core areas, K-feldspar and micas were sampled from blocky K-feldspar + quartz pods. Beryl, $\mathrm{Nb}$-Ta oxides, garnet and tourmaline were collected from all texturally distinct zones or units when available.

Unaltered and inclusion-free K-feldspar, muscovite and lepidolite were hand-picked from pegmatite samples for trace-element analysis. Samples were pulverized, sieved to $0.074 \mathrm{~mm}$, made into pressed pellets and analyzed using an automated Phillips X-ray fluorescence spectrometer (model PW1480). K-feldspar, mica-group minerals and beryl were analyzed for $\mathrm{Ba}, \mathrm{Cs}, \mathrm{Ga}, \mathrm{Ni}$, $\mathrm{Nb}, \mathrm{Pb}, \mathrm{Rb}, \mathrm{Sn}, \mathrm{Sr}, \mathrm{Ta}, \mathrm{Tl}, \mathrm{Zn}$ and $\mathrm{Zr}$. Lithium analyses were performed by direct current plasma-emission spectroscopy with a Spectrametrics Spectrascan V DCP in the laboratory of the Department of Earth and Environmental Sciences, University of New Orleans. Samples were digested either in $\mathrm{HF}$ or in a flux of $\mathrm{Na}_{2} \mathrm{CO}_{3} / \mathrm{NaOH}(1: 1)$. Standards were prepared with similar contents of $\mathrm{Na}^{+}$and $\mathrm{Cl}^{-}$ions to compensate for interferences.

Fragments and crystals of columbite-tantalite, tourmaline and garnet were placed in epoxy-filled Bakelite mounts, polished and analyzed using a JEOL Model JXA$8900 \mathrm{R}$ electron microprobe in the wavelength-dispersion mode. Four to six spots per grain were analyzed using an accelerating voltage of $15 \mathrm{kV}$, beam current of $20 \mathrm{nA}$ and a beam diameter of approximately 1 micron. Counting times for background and peak determinations were 5-10 s and 15-40 s, respectively for the various analyzed elements. Crystals were analyzed using the following standards: hornblende ( $\mathrm{Si}, \mathrm{Al}, \mathrm{Na}, \mathrm{K}, \mathrm{Ca}, \mathrm{Fe}, \mathrm{Mg}$ ), garnet ( $\mathrm{Si}, \mathrm{Al}, \mathrm{Fe})$, ilmenite ( $\mathrm{Ti}, \mathrm{Mn})$, synthetic $\mathrm{MnNb}_{2} \mathrm{O}_{6}(\mathrm{Mn}$, $\mathrm{Nb}), \mathrm{CaTa}_{4} \mathrm{O}_{11}(\mathrm{Ta}), \mathrm{Sc}_{2} \mathrm{TiO}_{5}(\mathrm{Sc})$, and $\mathrm{SnO}_{2}(\mathrm{Sn})$, gahnite $(\mathrm{Zn})$, apatite $(\mathrm{P}, \mathrm{F})$ and scapolite $(\mathrm{Cl})$. Data reduction was done using a conventional ZAF correction. The structural formula of tourmaline was calculated on the basis of 31 anions, assuming stoichiometric amounts of $\mathrm{B}_{2} \mathrm{O}_{3}$ as
$\left(\mathrm{BO}_{3}\right)^{-3}[\mathrm{~B}=3$ apfu $], \mathrm{H}_{2} \mathrm{O}$ as $(\mathrm{OH})^{-}$[i.e. $\mathrm{OH}+\mathrm{F}=4$ apfu $]$ and $\mathrm{Li}=3-\Sigma \mathrm{Y}$ apfu.

\subsection{Granite chemistry}

Representative whole-rock analyses of granitic rocks from the Sebago Pluton and SMD are given in Tab. 2. In the QAP and Ab-An-Or diagrams (Streckeisen 1973; O'Connor 1965), all samples plot within the granite field (Fig. 5a-b). The granites are peraluminous (A/CNK varies from 1.06 to 1.31 ) (Fig. 5c) and display a typical calc-alkaline trend on the AFM diagram (Fig. 5d). The trace-element data for the granites of the Sebago Pluton and SMD show similar levels of $\mathrm{Rb}, \mathrm{Cs}, \mathrm{Ba}, \mathrm{Sr}, \mathrm{Ga}, \mathrm{Pb}$ and $\mathrm{Nb}$ enrichment (Tab. 2), however, no systematic increases between groups of granites were observed. In general, group 1 granites have lower $\mathrm{K} / \mathrm{Rb}$ than the biotite granites of SMD. The K/Rb values of the twomica granites of the SMD overlap with those of the two-mica granites of the Sebago Pluton and the biotite granites of the SMD.

A number of diagrams have been used to discriminate the tectonic environment of granitic rocks. Figures $6 \mathrm{a}$ and $6 \mathrm{~b}$ show that the granites of the Sebago Pluton and SMD plot largely in the volcanic arc and syn-collisional granite field of the $\mathrm{Nb}$ vs. $\mathrm{Y}$ and $\mathrm{Rb}$ vs. $\mathrm{Y}+\mathrm{Nb}$ tectonic diagrams (Pearce et. al. 1984). Figure 6c (Batchelor and Bowden 1985) further supports a syn-collisional origin for the Sebago granites. Chondrite-normalized (Anders and Grevesse 1989) REE data for the Sebago granites are presented in Fig. 6d. The granites show uniform depletion of LREE and HREE, with LREE being more enriched relative to HREE. All granites display a negative Eu anomaly which varies more in the patterns of the SMD two-mica granites.

\subsection{Pegmatite mineral chemistry}

\subsubsection{K-feldspar}

$\mathrm{K}$-feldspar from the intermediate and core zones of all sampled pegmatites contains fine- to coarse-textured perthite. The bulk composition of K-feldspar shows minor variations in $\mathrm{Na}$ and $\mathrm{Ca}$ across the pegmatite population. $\mathrm{The} \mathrm{Na}_{2} \mathrm{O}$ contents vary from 0.31 to $3.37 \mathrm{wt}$. $\%$, whereas uniformly low levels of $\mathrm{CaO}(0.00-0.44 \mathrm{wt}$. $\%$ ) are typical of all pegmatites. The SPG K-feldspar is enriched in $\mathrm{Rb}$ (up to $6677 \mathrm{ppm}$ ) and Cs (up to 1045 $\mathrm{ppm})$. The highest $\mathrm{Rb}$ and $\mathrm{Cs}$ values are found in the Be- and Li-rich pegmatites of the SPG (Fig. 7a-b). The $\mathrm{Ga}$ and $\mathrm{Tl}$ contents (10 to $50 \mathrm{ppm}$ and 2 to $71 \mathrm{ppm}$, respectively) are fairly low throughout most of the SPG. Anomalously high $\mathrm{Ba}$ and $\mathrm{Sr}$ concentrations characterize 
Tab. 2 Representative whole-rock analyses of granitic rocks from the Sebago Pluton and SMD

\begin{tabular}{|c|c|c|c|c|c|c|c|c|c|c|}
\hline \multirow{2}{*}{$\begin{array}{l}\text { Granite Type } \\
\text { Sample No. }\end{array}$} & \multicolumn{4}{|c|}{ Sebago Granite (2-mica granite) } & \multicolumn{3}{|c|}{ SMD (biotite granite) } & \multicolumn{3}{|c|}{ SMD (2-mica granite) } \\
\hline & $\begin{array}{c}\text { SEBGR } \\
40 / \mathrm{A}\end{array}$ & $\begin{array}{c}\text { SEBGR } \\
41 / \mathrm{A}\end{array}$ & $\begin{array}{c}\text { SEBGR } \\
42 / \mathrm{A}\end{array}$ & $\begin{array}{c}\text { SEBGR } \\
43 / \mathrm{A}\end{array}$ & $\begin{array}{c}\text { CASCO } \\
4 / \mathrm{A}\end{array}$ & $\begin{array}{c}\text { SEBGR } \\
14 / A\end{array}$ & $\begin{array}{c}\text { SEBGR } \\
25 / \mathrm{A}\end{array}$ & $\begin{array}{c}\text { BLK CAT MTN } \\
5 / \mathrm{A} \\
\end{array}$ & $\begin{array}{c}\text { SEBGR } \\
20 / \mathrm{A}\end{array}$ & $\begin{array}{c}\text { SEBGR } \\
32 / \mathrm{A}\end{array}$ \\
\hline \multicolumn{11}{|c|}{ Major elements (wt.\%) } \\
\hline $\mathrm{P}_{2} \mathrm{O}_{5}$ & 0.12 & 0.12 & 0.15 & 0.11 & 0.09 & 0.08 & 0.09 & 0.11 & 0.09 & 0.09 \\
\hline $\mathrm{SiO}_{2}$ & 71.82 & 72.05 & 72.38 & 74.20 & 74.08 & 73.36 & 70.19 & 71.98 & 73.73 & 72.12 \\
\hline $\mathrm{TiO}_{2}$ & 0.22 & 0.20 & 0.18 & 0.11 & 0.12 & 0.23 & 0.34 & 0.30 & 0.27 & 0.28 \\
\hline $\mathrm{Al}_{2} \mathrm{O}_{3}$ & 15.11 & 14.81 & 15.10 & 14.90 & 14.48 & 14.54 & 16.37 & 15.44 & 13.60 & 14.84 \\
\hline $\mathrm{Fe}_{2} \mathrm{O}_{3}$ & 1.57 & 1.54 & 1.33 & 1.00 & 1.36 & 1.34 & 1.81 & 2.03 & 1.51 & 2.00 \\
\hline $\mathrm{MnO}$ & 0.05 & 0.04 & 0.04 & 0.04 & 0.03 & 0.02 & 0.02 & 0.04 & 0.03 & 0.02 \\
\hline $\mathrm{MgO}$ & 0.34 & 0.36 & 0.32 & 0.16 & 0.25 & 0.21 & 0.55 & 0.37 & 0.35 & 0.38 \\
\hline $\mathrm{CaO}$ & 1.09 & 1.26 & 1.06 & 0.82 & 1.13 & 0.93 & 1.73 & 0.82 & 0.51 & 0.96 \\
\hline $\mathrm{Na}_{2} \mathrm{O}$ & 3.91 & 3.63 & 3.38 & 3.36 & 3.35 & 3.01 & 3.54 & 2.88 & 2.28 & 3.38 \\
\hline $\mathrm{K}_{2} \mathrm{O}$ & 5.13 & 5.22 & 5.77 & 4.95 & 5.43 & 5.65 & 5.52 & 5.70 & 6.71 & 5.57 \\
\hline LOI & 0.58 & 0.61 & 0.56 & 0.66 & 0.39 & 0.59 & 0.45 & 0.74 & 1.12 & 0.54 \\
\hline Total & 99.94 & 99.84 & 100.27 & 100.31 & 100.71 & 99.96 & 100.61 & 100.41 & 100.20 & 100.18 \\
\hline \multicolumn{11}{|c|}{ Trace elements (ppm) } \\
\hline $\mathrm{Rb}$ & 355 & 298 & 352 & 373 & 314 & 219 & 245 & 324 & 213 & 267 \\
\hline $\mathrm{Cs}$ & 6 & 13 & 0 & 9 & 6 & 0 & 12 & 0 & 1 & 13 \\
\hline $\mathrm{Ba}$ & 329 & 523 & 336 & 138 & 340 & 378 & 369 & 333 & 204 & 371 \\
\hline $\mathrm{Sr}$ & 91 & 114 & 83 & 48 & 121 & 88 & 229 & 79 & 129 & 84 \\
\hline $\mathrm{Ga}$ & 23 & 21 & 32 & 26 & 20 & 25 & 21 & 28 & 11 & 24 \\
\hline $\mathrm{Tl}$ & 4 & 1 & 3 & 6 & 2 & 5 & 0 & 3 & 0 & 2 \\
\hline $\mathrm{Pb}$ & 41 & 18 & 32 & 25 & 31 & 31 & 30 & 17 & 67 & 45 \\
\hline $\mathrm{Nb}$ & 12 & 13 & 15 & 23 & 14 & 6 & 7 & 19 & 9 & 0 \\
\hline $\mathrm{Ta}$ & 7 & 1 & 4 & 7 & 5 & 4 & 4 & 2 & 4 & 4 \\
\hline $\mathrm{Sn}$ & 4 & 8 & 7 & 10 & 7 & 4 & 0 & 2 & 0 & 5 \\
\hline W & 6 & 3 & 4 & 9 & 5 & 1 & 6 & 6 & 2 & 0 \\
\hline $\mathrm{Cu}$ & 5 & 6 & 2 & 3 & 3 & 4 & 5 & 4 & 3 & 4 \\
\hline $\mathrm{Cr}$ & 1 & 0 & 1 & 0 & 0 & 0 & 0 & 3 & 0 & 0 \\
\hline Co & 0 & 0 & 0 & 0 & 0 & 0 & 0 & 1 & 0 & 1 \\
\hline $\mathrm{Ni}$ & 1 & 1 & 1 & 0 & 1 & 0 & 2 & 4 & 0 & 1 \\
\hline $\mathrm{V}$ & 14 & 15 & 9 & 7 & 9 & 6 & 18 & 13 & 1 & 8 \\
\hline $\mathrm{Y}$ & 19 & 20 & 17 & 17 & 29 & 8 & 7 & 14 & 9 & 12 \\
\hline $\mathrm{Zn}$ & 73 & 88 & 65 & 50 & 49 & 51 & 90 & 100 & 48 & 83 \\
\hline $\mathrm{Zr}$ & 140 & 147 & 120 & 56 & 115 & 134 & 102 & 148 & 118 & 173 \\
\hline $\mathrm{La}$ & 47.9 & 30.6 & 28.1 & 19.9 & 34.2 & 51.0 & 27.3 & 43.9 & 32.3 & 40.7 \\
\hline $\mathrm{Ce}$ & 93.8 & 58.6 & 56.6 & 37.6 & 66.3 & 110.0 & 60.0 & 92.8 & 80.7 & 88.1 \\
\hline $\operatorname{Pr}$ & 10.60 & 6.58 & 6.32 & 4.15 & 7.35 & 12.80 & 6.98 & 10.40 & 9.86 & 10.10 \\
\hline $\mathrm{Nd}$ & 34.1 & 21.2 & 20.8 & 13.0 & 23.6 & 42.8 & 24.4 & 35.1 & 33.7 & 34.0 \\
\hline $\mathrm{Sm}$ & 5.9 & 3.9 & 4.0 & 2.6 & 4.6 & 7.3 & 4.9 & 7.0 & 8.2 & 6.3 \\
\hline $\mathrm{Eu}$ & 0.65 & 0.58 & 0.52 & 0.30 & 0.68 & 0.68 & 0.84 & 0.59 & 0.51 & 0.46 \\
\hline $\mathrm{Gd}$ & 5.07 & 3.47 & 3.33 & 2.76 & 4.03 & 5.23 & 3.74 & 5.32 & 5.64 & 4.58 \\
\hline $\mathrm{Tb}$ & 0.61 & 0.41 & 0.44 & 0.45 & 0.66 & 0.54 & 0.34 & 0.62 & 0.57 & 0.55 \\
\hline Dy & 2.86 & 2.30 & 2.25 & 2.87 & 3.90 & 1.97 & 1.27 & 2.84 & 1.90 & 2.18 \\
\hline Ho & 0.50 & 0.46 & 0.41 & 0.58 & 0.81 & 0.26 & 0.15 & 0.40 & 0.24 & 0.30 \\
\hline $\mathrm{Er}$ & 1.20 & 1.36 & 1.07 & 1.62 & 2.37 & 0.58 & 0.31 & 0.74 & 0.51 & 0.51 \\
\hline $\mathrm{Tm}$ & 0.17 & 0.19 & 0.15 & 0.27 & 0.37 & 0.06 & 0.05 & 0.08 & 0.05 & 0.05 \\
\hline $\mathrm{Yb}$ & 1.0 & 1.2 & 1.0 & 1.8 & 2.4 & 0.3 & 0.3 & 0.4 & 0.4 & 0.3 \\
\hline $\mathrm{Lu}$ & 0.15 & 0.17 & 0.14 & 0.26 & 0.36 & 0.07 & 0.05 & 0.08 & 0.07 & 0.05 \\
\hline
\end{tabular}



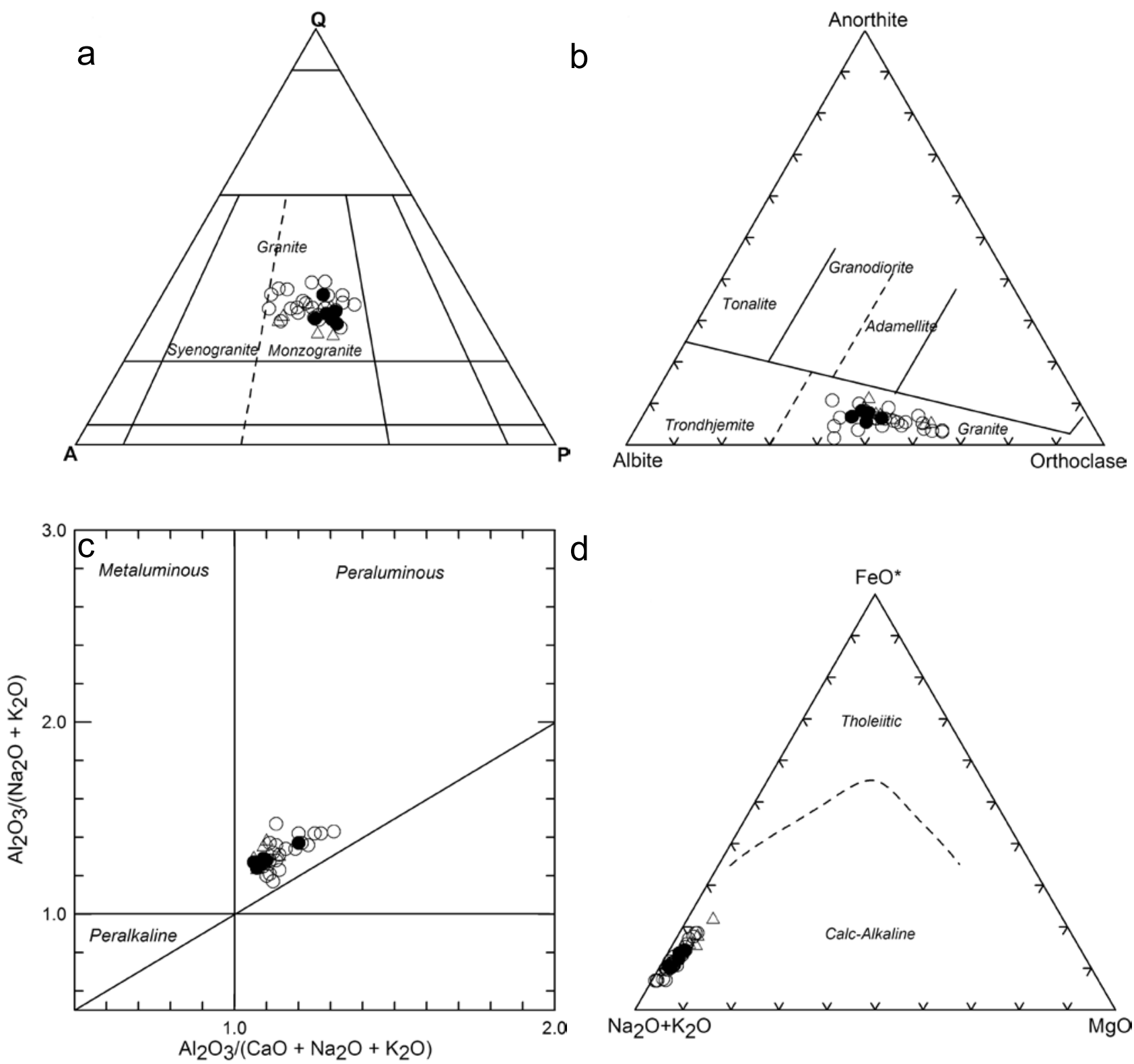

Fig. 5 QAP ternary plot based on modal compositions (Streckeisen 1979) (a) and normative Ab-An-Or (b) plot (O'Connor 1965) of the granites of the Sebago Pluton and Sebago Migmatite Domain. $\mathbf{c}$-Alumina saturation (Shand index) diagram for the studied Sebago granites (modified after Maniar and Piccoli 1989). d - The AFM $\left(\mathrm{Na}_{2} \mathrm{O}+\mathrm{K}_{2} \mathrm{O}-\mathrm{FeO}^{*}-\mathrm{MgO}\right)$ plot (from Irvine and Baragar 1971) illustrating calc-alkaline trend of Sebago and SMD granites. Symbols: Dots - group 1 two-mica granite, circles - group 2 two-mica granite, open triangles - group 2 biotite granite.

the Ragged Jack K-feldspar $(\mathrm{Ba}=1239-1971 \mathrm{ppm}$ and $\mathrm{Sr}=310-360 \mathrm{ppm})$, but for much of the SPG Ba and $\mathrm{Sr}$ contents are typically lower than $300 \mathrm{ppm}$ and $100 \mathrm{ppm}$, respectively. K-feldspar from the Sebago pegmatites commonly shows large variations in its $\mathrm{K} / \mathrm{Rb}, \mathrm{K} / \mathrm{Cs}$ and $\mathrm{K} / \mathrm{Ba}$ ratios (Tab. 3).

\subsubsection{Muscovite}

The principal primary mica species dominating the SPG is muscovite, although biotite and lepidolite are locally abun- dant in some pegmatites. Silver-colored platy muscovite is abundant in most pegmatites with the exception of the most primitive types (e.g. Conant, Songo Pond) where muscovite occurs only as a few scattered flakes. Yellowish muscovite is common only in highly-fractionated pegmatites, such as at Mt. Mica or Pulsifer, and is usually found near the margins of the core or along the edges of miarolitic cavities. Coarse-grained books of muscovite may show a diamond-shaped habit, sometimes with curved-faces; occasionally they are rimmed by a later generation of pale, lilac-colored muscovite. Lenses and pods of massive, me- 

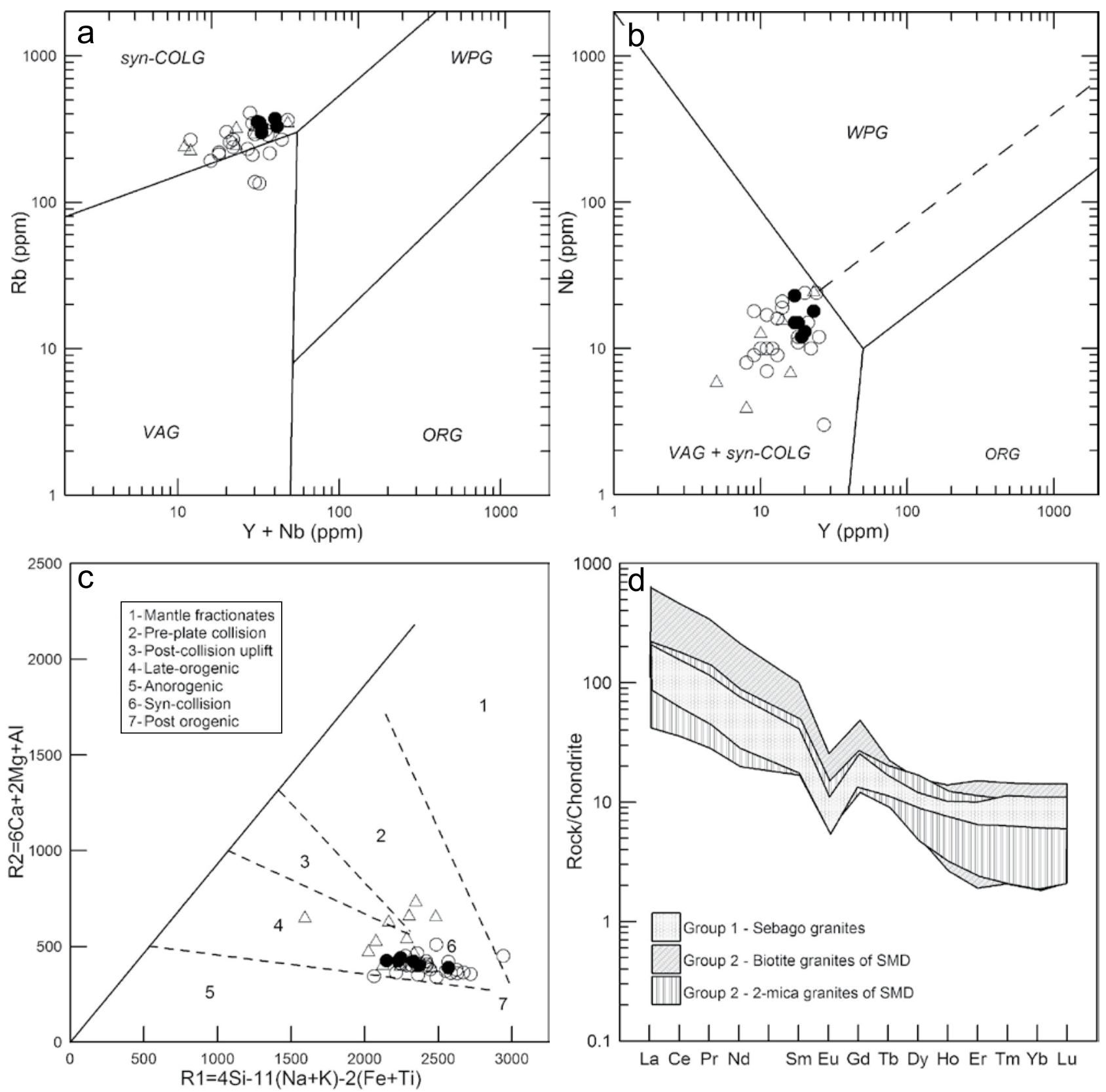

Fig. $6 \mathrm{Rb}-\mathrm{Y}+\mathrm{Nb}(\mathbf{a})$ and $\mathrm{Nb}-\mathrm{Y}$ (b) tectonic discrimination of the Sebago Pluton and granites of the Sebago Migmatite Domain (Pearce et al. 1984). $\mathbf{c}-R_{1}-R_{2}$ diagram (Batchelor and Bowden 1985) of Sebago granites. d - Chondrite-normalized REE plot for studied granites of the Sebago Pluton and Sebago Migmatite Domain. REE concentrations are normalized to the chondritic values of Anders and Grevesse (1989). Symbols: Dots - group 1 two-mica granite, circles - group 2 two-mica granite, open triangles - group 2 biotite granite.

dium- to fine-grained silver- to lilac-colored, Li-enriched muscovite are restricted to highly-evolved pegmatites, particularly those containing spodumene or petalite, and are most common as late replacement units situated in the innermost intermediate zones.

Muscovite compositions show variable concentrations of $\mathrm{Mg}$, $\mathrm{Ti}$ and $\mathrm{Fe}$. Low $\mathrm{MgO}$ and $\mathrm{TiO}_{2}$ characterize much of the pegmatite population with total $\mathrm{MgO}+\mathrm{TiO}_{2}$ typically $<0.75$ wt. \%. Overall, $\mathrm{Fe}$ concentrations range from 1.27 to 4.55 wt. $\% \mathrm{Fe}_{2} \mathrm{O}_{3}$, but a few pegmatites in the western part of the group (e.g., Lord Hill, Songo Pond and Eastman) contain muscovite that exceeds 5 wt. \% $\mathrm{Fe}_{2} \mathrm{O}_{3}$ (Tab. 4).

Figures 7 and 8 illustrate the fractionation of rare alkalis ( $\mathrm{Rb}, \mathrm{Cs}$ and $\mathrm{Li}$ ), Ta, $\mathrm{Sn}$ and $\mathrm{Zn}$ in muscovite from the $\mathrm{SPG}$. The $\mathrm{K} / \mathrm{Rb}$ ratio, which serves as an effective fractionation indicator (Černý et al. 1981, 1985; Tomascak 1991) ranges from 155 to 10 for the SPG muscovites. Ru- 

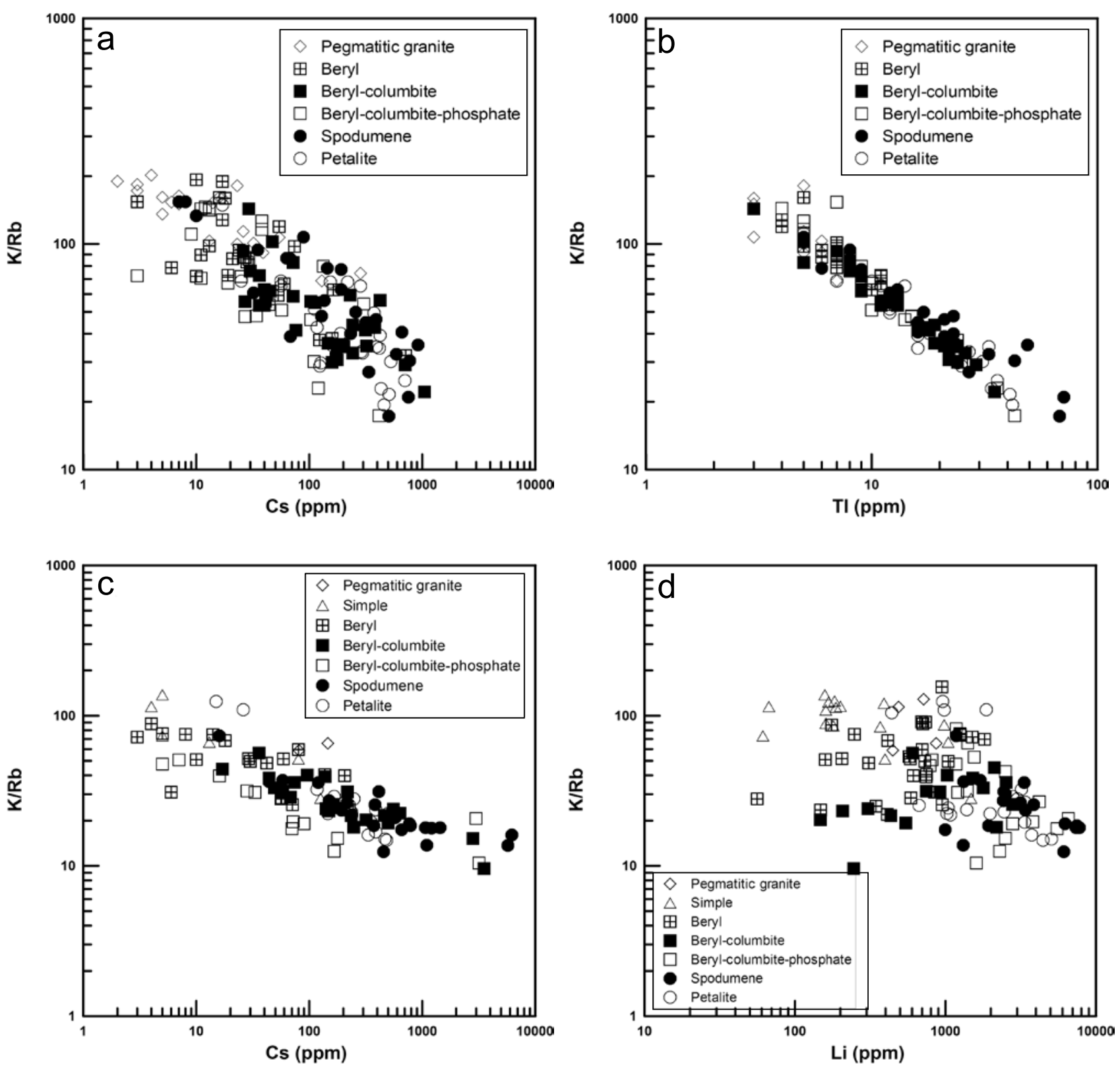

Fig. 7 Plot of $\mathrm{K} / \mathrm{Rb}$ vs. Cs (a) and $\mathrm{K} / \mathrm{Rb}$ vs. $\mathrm{Tl}$ (b) in K-feldspar from the Sebago group pegmatites. Plot of $\mathrm{K} / \mathrm{Rb}$ vs. Cs (c) and $\mathrm{K} / \mathrm{Rb}$ vs. $\mathrm{Li}$ (d) in muscovite from the Sebago group pegmatites.

bidium fractionation in the muscovites is similar to that observed in K-feldspar, and although most muscovites typically contain less than $5000 \mathrm{ppm} \mathrm{Rb}$, extreme levels $(>7500 \mathrm{ppm} \mathrm{Rb})$ were observed in the most evolved pegmatites (e.g., Bennett, Hayes and BB\#7).

Most of the SPG muscovites do not attain high levels of $\mathrm{Li} ; \mathrm{Li}_{2} \mathrm{O}$ contents range from $0.20 \mathrm{wt}$. $\%$ to $0.62 \mathrm{wt}$. $\%$. High $\mathrm{Li}$ contents $\left(>1.0\right.$ wt. $\left.\% \mathrm{Li}_{2} \mathrm{O}\right)$ are generally found in muscovites from pegmatites carrying spodumene (e.g. Bennett), petalite (e.g. Emmons) or Li-phosphates (e.g., Berry-Havey). Despite the absence of Li minerals,

Tab. 3 Trace-element data for Sebago Pegmatite Group K-feldspars

\begin{tabular}{lccc}
\hline & Pegmatitic granite & Be-pegmatites & Li-pegmatites \\
\hline $\mathrm{Rb}(\mathrm{ppm})$ & $503-1446$ & $522-6079$ & $666-6677$ \\
$\mathrm{Cs}$ & $5-283$ & $3-1045$ & $7-917$ \\
$\mathrm{Tl}$ & $3-9$ & $3-43$ & $5-71$ \\
$\mathrm{Ba}$ & $1-199$ & $1-537$ & $2-423$ \\
$\mathrm{Sr}$ & $4-85$ & $4-255$ & $8-106$ \\
$\mathrm{~K} / \mathrm{Rb}$ & $68.8-201.7$ & $17.3-192.9$ & $17.3-154$ \\
$\mathrm{~K} / \mathrm{Cs}$ & $345-3-48356.3$ & $97.2-32957$ & $122.8-14824.1$ \\
$\mathrm{~K} / \mathrm{Ba}$ & $509.8-97708.8$ & $178.7-99950.2$ & $242.9-50805.2$ \\
$\mathrm{Rb} / \mathrm{Sr}$ & $5.9-289.2$ & $5.6-878$ & $6.3-413.8$ \\
\hline
\end{tabular}

Table is exclusive of anomalous Ragged Jack data: $\mathrm{Rb}=275-294$, $\mathrm{Cs}=0-8, \mathrm{Tl}=0, \mathrm{Ba}=1239-1971, \mathrm{Sr}=310-360, \mathrm{~K} / \mathrm{Rb}=377-409$, $\mathrm{K} / \mathrm{Cs}=0-13822, \mathrm{~K} / \mathrm{Ba}=56-91, \mathrm{Rb} / \mathrm{Sr}=0.8$ 
Tab. 4 Partial analysis of Sebago Pegmatite Group muscovites

\begin{tabular}{|c|c|c|c|c|}
\hline & Pegmatitic granites & Simple pegmatites & Be-pegmatites & Li-pegmatites \\
\hline $\mathrm{Na}_{2} \mathrm{O}$ (wt. \%) & $0.41-0.65$ & $0.37-0.68$ & $0.51-0.70$ & $0.49-0.61$ \\
\hline $\mathrm{Fe}_{2} \mathrm{O}_{3} *$ & $1.46-3.85$ & $1.27-3.19$ & $2.06-4.17$ & $2.03-4.55$ \\
\hline $\mathrm{MgO}$ & $0.07-0.49$ & $0.07-0.74$ & $0.06-0.72$ & $0.07-1.15$ \\
\hline $\mathrm{TiO}_{2}$ & $0.01-0.16$ & $0.03-0.68$ & $0.05-0.58$ & $0.07-1.28$ \\
\hline $\mathrm{Ba}(\mathrm{ppm})$ & $3-66$ & $2-287$ & $1-218$ & $1-42$ \\
\hline Cs & $81-146$ & $4-126$ & $0-3533$ & $15-6236$ \\
\hline $\mathrm{Ga}$ & $94-109$ & $80-235$ & $91-330$ & $127-367$ \\
\hline $\mathrm{Li}$ & $447-867$ & $61-1481$ & $56-6553$ & $439-7778$ \\
\hline $\mathrm{Nb}$ & $94-276$ & $90-376$ & $18-547$ & $41-431$ \\
\hline $\mathrm{Rb}$ & $747-1613$ & $701-3324$ & $617-9600$ & $768-7598$ \\
\hline Sn & $65-285$ & $29-285$ & $68-1783$ & $70-1501$ \\
\hline $\mathrm{Sr}$ & $4-7$ & $3-18$ & $3-22$ & $3-9$ \\
\hline $\mathrm{Ta}$ & $8-39$ & $7-107$ & $7-393$ & $11-215$ \\
\hline $\mathrm{Tl}$ & $46-59$ & $33-77$ & $37-151$ & $36-123$ \\
\hline $\mathrm{Zn}$ & $53-98$ & $37-358$ & $60-1138$ & $57-947$ \\
\hline $\mathrm{Zr}$ & $8-13$ & $3-16$ & $1-145$ & $3-68$ \\
\hline $\mathrm{K} / \mathrm{Rb}$ & $58.7-128.6$ & $28.2-137.8$ & $9.6-155.4$ & $12.4-124.5$ \\
\hline
\end{tabular}

* Table does not include anomalous $\mathrm{Fe}_{2} \mathrm{O}_{3}$ data for Bennett (4.90-5.24 wt. \%), Lord Hill (3.13-7.10), Songo Pond (5.26-5.74), and Eastman (3.26-5.12) pegmatites.

muscovite from the Lord Hill pegmatite may contain up to 1.19 wt. $\% \mathrm{Li}_{2} \mathrm{O}$. True lepidolite, $\mathrm{KLi}_{2} \mathrm{Al}(\mathrm{Al}, \mathrm{Si})_{3} \mathrm{O}_{10}$ $(\mathrm{F}, \mathrm{OH})_{2},\left(>4.0\right.$ wt. $\left.\% \mathrm{Li}_{2} \mathrm{O}\right)$ was found only as finegrained veinlets cross cutting pollucite and kaolinized spodumene.

High cesium concentrations are best seen in muscovite from the highly fractionated and pollucite-bearing Bennett, Mt. Mica, Westinghouse and GE pegmatites, where $\mathrm{Cs}_{2} \mathrm{O}$ values approach 1 wt. \%. However, the Cs concentration for most muscovite in the SPG is generally $<400$ ppm. Tin contents of muscovite range from $\sim 25$ to $\sim 1800$ ppm with the highest levels generally found in pegmatites that carry substantial amounts of columbite group minerals or cassiterite. The concentration of $\mathrm{Nb}$ and $\mathrm{Ta}$ in SPG muscovite typically lies in the interval 200-500 ppm and 10-100 ppm, respectively. Tantalum concentrations in muscovite generally increase with the degree of pegmatite fractionation in all pegmatite subtypes. Zinc shows similar patterns of enrichment as Sn and typically attains less than 500 ppm (Fig. 8).

\subsubsection{Garnet}

Garnet from the SPG is generally found in the wall and intermediate zones of both simple and complex pegmatites. It occurs as dark red to purple-red crystals as much as $3 \mathrm{~cm}$ in diameter in pegmatitic granite, whereas garnets from pegmatites are generally dark red and rarely pink or orange. Locally, some crystals display symplectic intergrowths with quartz or fluorapatite or are envel- oped by a 1 to $2 \mathrm{~mm}$ thick rim of dark blue tourmaline. Concentrations of garnet along the margins of partially digested xenoliths of biotite schist may be found in some pegmatites. Garnet-rich bands (garnet seams) 1 to $5 \mathrm{~cm}$ thick, rarely occur in some pegmatites and pegmatitic leucogranites (Fig. 3d). Individual crystals within the garnet seams range in size from $2 \mathrm{~mm}$ to $3 \mathrm{~cm}$ and are associated with platy albite (cleavelandite), smoky quartz and schorl. Dark red garnet crystals, $1 \mathrm{~mm}$ or less in diameter, occur in schorl-bearing aplite in some zoned pegmatites (e.g. Bennett, Westinghouse, GE); garnetiferous aplite without schorl occurs locally at the Lord Hill pegmatite.

Garnet compositions for the Sebago pegmatites (Tab. 5) correspond typically to almandine with a few localities containing spessartine. Microprobe traverses across single crystals show chemical zoning expressed by $\mathrm{Mn}$-enriched rims and Fe-enriched cores. Pyrope and andradite components are minor; combined $\mathrm{MgO}$ and $\mathrm{CaO}$ contents are generally less than 2 wt. \%. Phosphorus concentrations range from $<0.1$ to 0.64 wt. $\% \mathrm{P}_{2} \mathrm{O}_{5}$ with nearly $25 \%$ of analyses containing more than 0.2 wt. $\%$ (Wise 1994). The distribution of phosphorus within individual crystals is irregular and zonation is virtually absent. Pegmatites hosting multi-generations of garnet show systematic variations in $\mathrm{Mn} /(\mathrm{Mn}+\mathrm{Fe})$ values, $\mathrm{Mg}$ and $\mathrm{P}$. Early generations of garnet tend to have higher $\mathrm{Mg}$ and lower average $\mathrm{P}$ and $\mathrm{Mn} /(\mathrm{Mn}+\mathrm{Fe})$ values than garnet found in later generations. Aside from local Mn enrichment $(\mathrm{Mn} /(\mathrm{Mn}+\mathrm{Fe})>0.5$ in the Bennett, Westinghouse, 

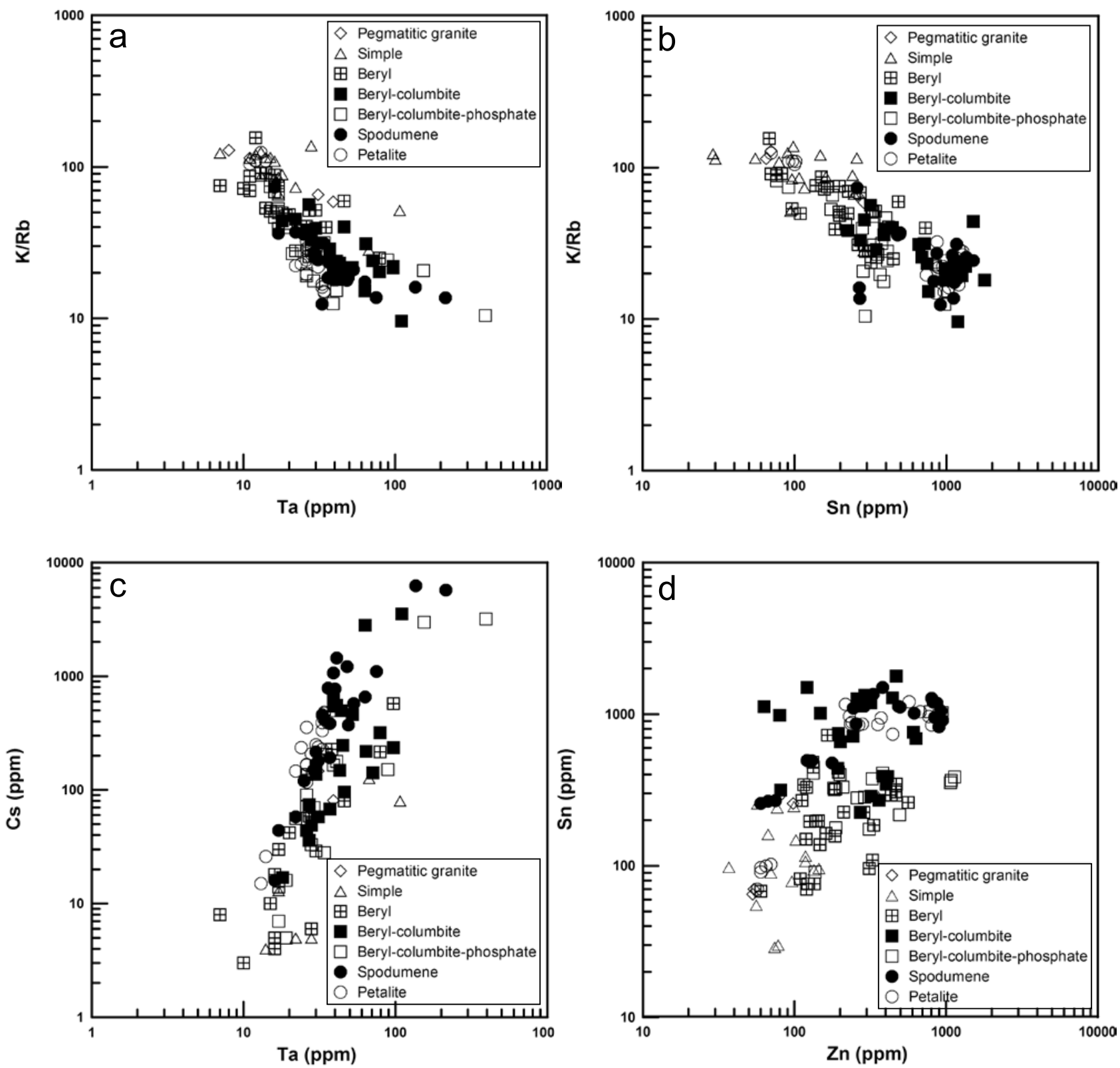

Fig. $8 \mathrm{~K} / \mathrm{Rb}$ vs. Ta (a) and Sn (b) plot of Sebago Pegmatite Group muscovite. Cs vs. Ta (c) and Sn vs. Zn (d) for muscovite.

$\mathrm{GE}$ and Emmons pegmatites), $\mathrm{Mn} /(\mathrm{Mn}+\mathrm{Fe})$ values are relatively uniform throughout the pegmatite group (Fig. 9). In contrast, P levels tend to be highest in pegmatites east of the Songo Pluton. No systematic difference in $\mathrm{Mn}$ or $\mathrm{P}$ contents was observed among different subtypes of rare-element pegmatites.

\subsubsection{Beryl}

Beryl is a widespread accessory phase found in moderately- to highly-evolved pegmatites of the SPG. Yellow, green and blue-green anhedral masses or columnar, hexagonal crystals (up to $8.2 \mathrm{~m}$ in length; Neumann
1952) are typical of simple pegmatites or the outer zones of evolved pegmatites. By comparison, inner zones of evolved pegmatites typically host blue and milky-white beryl. Beryl occurring in miarolitic cavities is typically blue, pink, white, colorless, rarely yellow-green (e.g. Orchard Pit) and is often etched. It can rarely be translucent to transparent and of good gem quality. Although beryl appears to be equally distributed over the entire pegmatite population, pink to colorless beryl is rarely found in pegmatites west of the Songo Pluton.

The chemical composition of the SPG beryl varies within narrow limits of their $\mathrm{Na}_{2} \mathrm{O}, \mathrm{Fe}_{2} \mathrm{O}_{3}$ and $\mathrm{Ga}$ contents (Tab. 6). For most beryl in the SPG, Rb content is 
Tab. 5 Selected electron microprobe compositions of garnet from the Sebago Pegmatite Group

\begin{tabular}{|c|c|c|c|c|c|c|c|c|}
\hline & 1 & 2 & 3 & 4 & 5 & 6 & 7 & 8 \\
\hline $\mathrm{P}_{2} \mathrm{O}_{5}$ & 0.41 & 0.08 & 0.17 & 0.05 & 0.10 & 0.09 & 0.06 & 0.12 \\
\hline $\mathrm{SiO}_{2}$ & 36.36 & 36.71 & 36.39 & 36.80 & 36.86 & 36.51 & 36.97 & 36.66 \\
\hline $\mathrm{TiO}_{2}$ & 0.05 & 0.01 & 0.07 & 0.06 & 0.06 & 0.03 & 0.03 & 0.03 \\
\hline $\mathrm{ZrO}_{2}$ & 0.00 & 0.00 & 0.05 & 0.00 & 0.00 & 0.02 & 0.00 & 0.03 \\
\hline $\mathrm{Al}_{2} \mathrm{O}_{3}$ & 21.24 & 21.26 & 21.30 & 21.25 & 21.41 & 21.24 & 21.27 & 21.01 \\
\hline $\mathrm{Y}_{2} \mathrm{O}_{3}$ & 0.00 & 0.13 & 0.00 & 0.00 & 0.04 & 0.01 & 0.00 & 0.00 \\
\hline $\mathrm{FeO}$ & 24.37 & 28.30 & 20.21 & 34.06 & 29.94 & 28.29 & 26.98 & 24.47 \\
\hline $\mathrm{MnO}$ & 17.57 & 11.73 & 22.22 & 6.82 & 10.03 & 13.17 & 12.99 & 16.53 \\
\hline $\mathrm{CaO}$ & 0.19 & 0.71 & 0.20 & 0.72 & 0.43 & 0.44 & 0.41 & 0.27 \\
\hline $\mathrm{MgO}$ & 0.07 & 0.52 & 0.04 & 0.33 & 1.17 & 0.49 & 1.07 & 0.94 \\
\hline $\mathrm{Na}_{2} \mathrm{O}$ & 0.00 & 0.00 & 0.00 & 0.00 & 0.01 & 0.05 & 0.00 & 0.02 \\
\hline Total & 100.25 & 99.44 & 100.64 & 100.09 & 100.03 & 100.35 & 99.77 & 100.07 \\
\hline \multicolumn{9}{|c|}{ Number of cations on the basis of 12 oxygens } \\
\hline $\mathrm{P}^{5+}$ & 0.028 & 0.005 & 0.012 & 0.004 & 0.007 & 0.006 & 0.004 & 0.008 \\
\hline $\mathrm{Si}^{4^{+}}$ & 2.973 & 3.009 & 2.972 & 3.007 & 2.996 & 2.982 & 3.012 & 2.994 \\
\hline Z-site sum & 3.001 & 3.014 & 2.984 & 3.011 & 3.003 & 2.988 & 3.016 & 3.002 \\
\hline$\overline{\mathrm{Ti}^{4+}}$ & 0.003 & 0.000 & 0.004 & 0.004 & 0.004 & 0.002 & 0.002 & 0.002 \\
\hline $\mathrm{Zr}^{4+}$ & 0.000 & 0.000 & 0.002 & 0.000 & 0.000 & 0.001 & 0.000 & 0.001 \\
\hline $\mathrm{Al}^{3+}$ & 2.047 & 2.054 & 2.051 & 2.046 & 2.051 & 2.045 & 2.043 & 2.022 \\
\hline $\mathrm{Y}^{3+}$ & 0.000 & 0.006 & 0.000 & 0.000 & 0.002 & 0.000 & 0.000 & 0.000 \\
\hline Y-site sum & 2.050 & 2.060 & 2.057 & 2.050 & 2.057 & 2.048 & 2.045 & 2.025 \\
\hline $\mathrm{Fe}^{2+}$ & 1.666 & 1.940 & 1.380 & 2.327 & 2.035 & 1.932 & 1.839 & 1.671 \\
\hline $\mathrm{Mn}^{2+}$ & 1.217 & 0.814 & 1.537 & 0.472 & 0.690 & 0.911 & 0.896 & 1.143 \\
\hline $\mathrm{Ca}^{2+}$ & 0.016 & 0.062 & 0.017 & 0.063 & 0.038 & 0.039 & 0.036 & 0.024 \\
\hline $\mathrm{Mg}^{2+}$ & 0.008 & 0.063 & 0.005 & 0.040 & 0.141 & 0.060 & 0.129 & 0.114 \\
\hline $\mathrm{Na}^{+}$ & 0.000 & 0.000 & 0.000 & 0.000 & 0.002 & 0.008 & 0.000 & 0.003 \\
\hline $\mathrm{X}$-site sum & 2.907 & 2.879 & 2.939 & 2.902 & 2.906 & 2.950 & 2.900 & 2.955 \\
\hline Total & 7.958 & 7.953 & 7.980 & 7.963 & 7.966 & 7.986 & 7.961 & 7.982 \\
\hline $\mathrm{Mn} /(\mathrm{Mn}+\mathrm{Fe})$ & 0.42 & 0.30 & 0.53 & 0.17 & 0.25 & 0.32 & 0.33 & 0.41 \\
\hline $\mathrm{Ca} /(\mathrm{Ca}+\mathrm{Mg})$ & 0.66 & 0.50 & 0.76 & 0.61 & 0.21 & 0.39 & 0.22 & 0.17 \\
\hline
\end{tabular}

1 - Mt. Marie, 2 - Pulsifer, 3 - GE, 4 - Norman Jack, 5 - Tamminen, 6 - Tiger Bill, 7 - Bumpus, 8 - Songo Pond.

minimal $(<200 \mathrm{ppm})$ and its concentration increases with increasing Cs (Fig. 10a). The geochemical trend of $\mathrm{Na} / \mathrm{Li}$ versus Cs observed in the Sebago data is consistent with beryl chemistry from other pegmatite fields (Fig. 10b; Černý 1975; Černý et al. 1981). In general, yellow, green and blue-green varieties of beryl have 1000-5000 ppm Cs. By comparison, the pink, white or colorless crystals found only in the most evolved pegmatites, such as the Bennett pegmatite, may contain between 1 and $3.0 \mathrm{wt}$ \% $\mathrm{Cs}_{2} \mathrm{O}$.

\subsection{5. $\mathrm{Nb}-\mathrm{Ta}-\mathrm{Sn}-\mathrm{Ti}$ oxides}

The Nb, Ta, Sn and Ti mineralization within the SPG is represented largely by the columbite-group minerals and, to a lesser degree, by cassiterite, ixiolite, wodginite, ferrotapiolite, and rutile. Columbite-group minerals occur as black, bladed to columnar, subhedral to euhedral crystals that are as large as $21 \mathrm{~cm}$ in maximum dimension. Most, however, are on the order of 0.5 to $2 \mathrm{~cm}$ in size. Cassiterite is found most often in Li-enriched pegmatites of the SPG group as black, dark brown or dark reddish-brown, anhedral masses ranging in size from $0.5 \mathrm{~cm}$ to approximately $3-4 \mathrm{~cm}$ in diameter. Exceptionally large cassiterite is unusual in the SPG; the BB\#7 pegmatite produced a very large crystal nearly $20 \mathrm{~cm}$ in diameter and a mass of cassiterite weighing up to $90 \mathrm{~kg}$ was reported from the Bennett pegmatite (Landes 1925). Sharp pyramidal crystals, rarely twinned, occur locally in miarolitic cavities. The Bennett and Emmons pegmatites are the only localities in the SPG known to contain wodginite or ixiolite. Both minerals form subhedral masses or occur as inclusions in columbite-tantalite. Ferrotapiolite is rare and so far found only in the Bennett and Mt. Mica pegmatites, while small grains of Fe-enriched, niobian rutile has only been found at the Songo Pond pegmatite. All of the aforementioned 


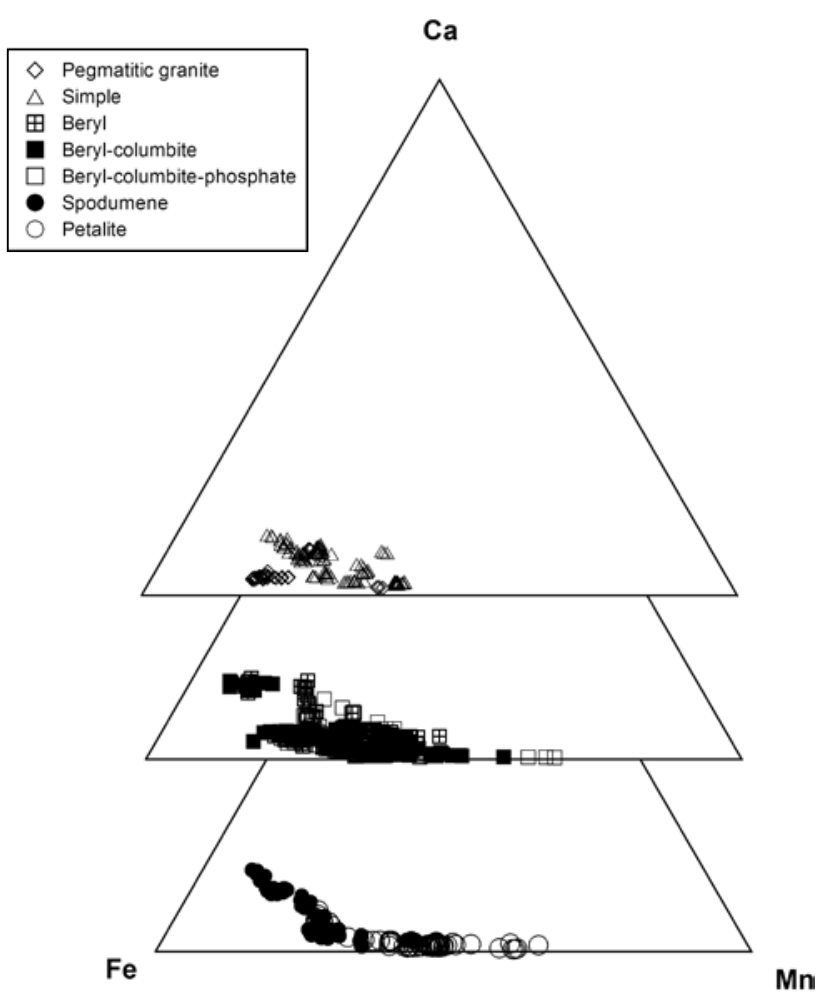

Fig. 9 Composition of garnet from the Sebago Pegmatite Group in the $\mathrm{Fe}-\mathrm{Mn}-\mathrm{Ca}$ triangle (atomic).

minerals are commonly found in assemblages dominated by platy albite although some may be found in milky to smoky quartz or in assemblages hosting fine- to mediumgrained silver, pale-green or purple Li-enriched mica or lepidolite.

Electron microprobe analyses of columbite-group minerals reveal an extensive range of $\mathrm{Mn} /(\mathrm{Mn}+\mathrm{Fe})$ and $\mathrm{Ta} /(\mathrm{Ta}+\mathrm{Nb})$ values (Tab. 7). Compositions range from predominantly ferrocolumbite and manganocolumbite with narrow ranges of $\mathrm{Nb}-\mathrm{Ta}$ substitution to subordinate manganotantalite with limited ranges of Fe-Mn substitution (Fig. 10c). Columbite-group minerals typically show a concomitant increase in Ta and $\mathrm{Mn}$, which is a common trend displayed with progressive pegmatite fractionation. Total $\mathrm{Fe}_{2} \mathrm{O}_{3}, \mathrm{Sc}_{2} \mathrm{O}_{3}, \mathrm{TiO}_{2}, \mathrm{SnO}_{2}$ and $\mathrm{WO}_{3}$ contents in the columbite-group minerals are generally less than 0.5 wt. \%. Columbite-group minerals from pegmatites east of the Songo Pluton carry the highest $\mathrm{SnO}_{2}$ values while $\mathrm{TiO}_{2}, \mathrm{Sc}_{2} \mathrm{O}_{3}$ and $\mathrm{Fe}_{2} \mathrm{O}_{3}$ are the highest in pegmatites west of the Songo Pluton.

Cassiterite is more common in beryl-, spodumeneand petalite-bearing pegmatites, whereas ferrotapiolite, wodginite and ixiolite are rare. Cassiterite contains low to moderate amounts of $\mathrm{Nb}$ and $\mathrm{Ta}$; maximum $\mathrm{Nb}_{2} \mathrm{O}_{5}$ and $\mathrm{Ta}_{2} \mathrm{O}_{5}$ contents are 1.79 wt. $\%$ and 7.07 wt. $\%$, respectively. All wodginite and ixiolite from the Emmons and Bennett pegmatites are Sn-rich and contain up to
Tab. 6 Partial analysis of Sebago Group beryl

\begin{tabular}{lcc}
\hline & Be-pegmatites & Li-pegmatites \\
\hline $\mathrm{Cs}(\mathrm{ppm})$ & $158-10596$ & $435-29743$ \\
$\mathrm{Ga}$ & $20-79$ & $25-63$ \\
$\mathrm{Li}$ & $261-3903$ & $537-5513$ \\
$\mathrm{Rb}$ & $17-447$ & $63-325$ \\
$\mathrm{Zn}$ & $37-575$ & $22-461$ \\
$\mathrm{Zr}$ & $1-148$ & $2-208$ \\
$\mathrm{Na} / \mathrm{Li}$ & $0.96-9.38$ & $0.83-6.65$ \\
\hline
\end{tabular}

19.19 wt. $\% \mathrm{SnO}_{2}, 12.08$ wt. $\% \mathrm{Nb}_{2} \mathrm{O}_{5}$ and typically low $\mathrm{TiO}_{2}$ contents (0.0-2.55 wt. \%). The Songo Pond rutile contains $12.38-19.11$ wt. $\% \mathrm{Nb}_{2} \mathrm{O}_{5}, 4.44-14.56$ wt. $\%$ $\mathrm{Ta}_{2} \mathrm{O}_{5}$ and up to 1.73 wt. $\% \mathrm{SnO}_{2}, 1.27$ wt. $\% \mathrm{WO}_{3}$ and 0.64 wt. $\% \mathrm{Sc}_{2} \mathrm{O}_{3}$.

\subsubsection{Tourmaline}

Tourmaline occurs as a common accessory phase in nearly all of the pegmatites of the SPG with the exception of those that intrude the SMD west of the Songo Pluton where tourmaline is generally scarce. Pegmatites west of the Songo Pluton carry only Mg- and Fe-dominant tourmaline, whereas pegmatites from the rest of the group may contain substantial amounts of Li-rich tourmalines. Tourmaline is found as single, prismatic crystals (up to $54 \mathrm{~cm}$ long; Simmons et al. 2005), sometimes growing perpendicular to the pegmatite margin, as radial aggregates, or as graphic intergrowths with quartz. The most common tourmaline species are schorl and elbaite; dravite and foitite are rare. Tourmaline from the simple pegmatites is typically schorl, while those from the more mineralogically and texturally diverse pegmatites often display various colors typical of elbaite which reflects changes in the tourmaline chemistry. From the pegmatite margins to the core, the color of tourmaline frequently varies systematically from black (schorl or foitite) to dark blue (schorl-elbaite) to green (elbaite) to pink (elbaite) and ultimately colorless (elbaite). Normal zoning (e.g. Fe-enriched cores relative to the rims) is common, but reverse, patchy and oscillatory zoning also occurs. Tourmalines from miarolitic cavities may be of gem-quality and can show considerable etching effects. Crystals of brown dravite commonly occur at the margins of xenoliths and pegmatite-host rock contacts, except at the Songo Pond pegmatite, where dravite is unrelated to any xenoliths or contacts. Foitite was identified from some primitive pegmatites (e.g. Sahib and Green) and from the wall zones of Li-enriched pegmatites (e.g. Mt. Marie and Mt. Rubellite pegmatites).

Chemical variation of tourmaline within the SPG is extensive (Tab. 8). This variation is due largely to $\mathrm{Mg}-$ $\mathrm{Fe}-\mathrm{Al}-\mathrm{Li}$ substitution in the $Y$-site of the tourmaline 

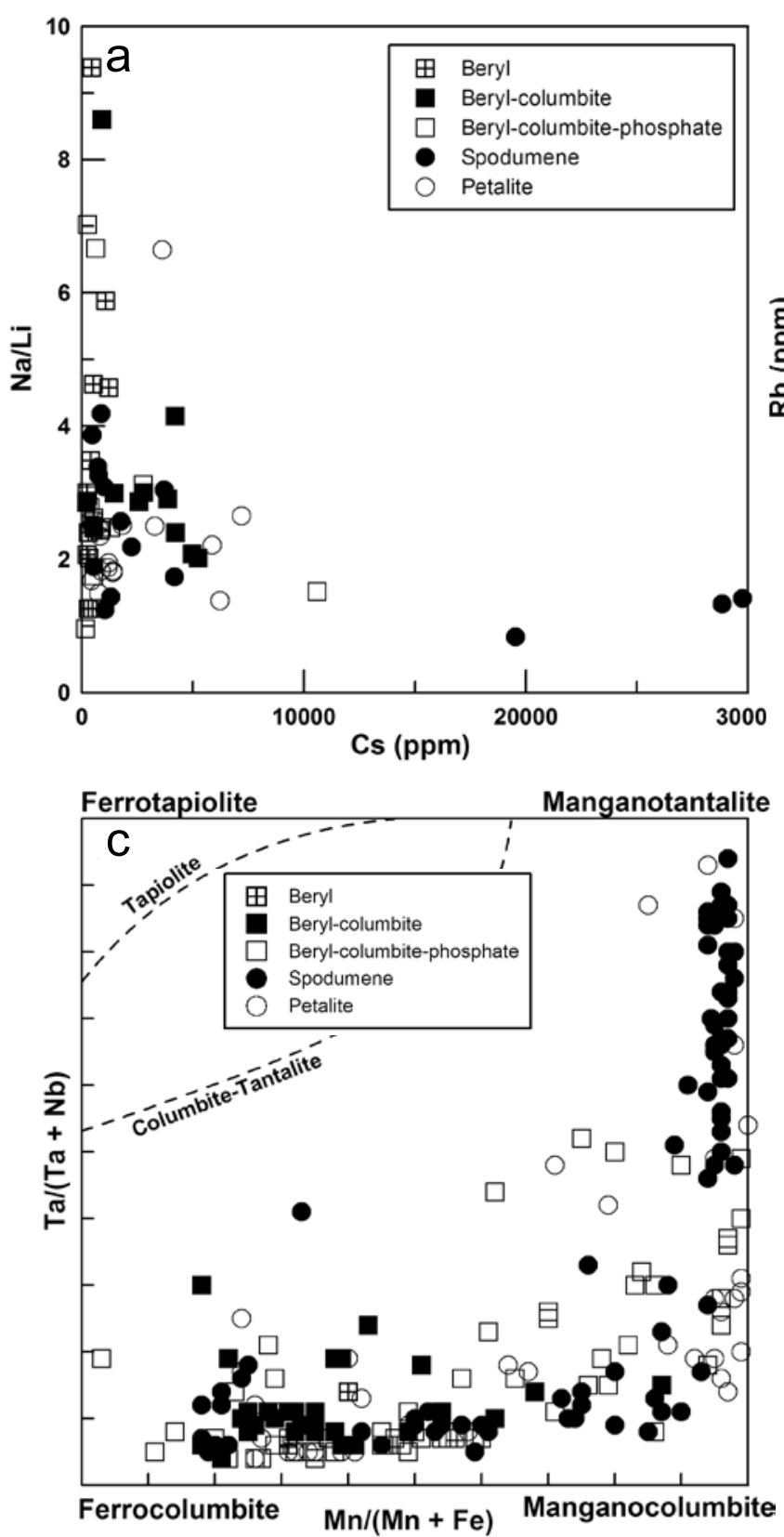

structure and, to a lesser degree, to the incorporation of $X$-site vacancies, which result in significant foitite or rossmanite components in the tourmaline chemistry. Overall, $X$-site vacancies range from 0.20 to 0.50 apfu for schorl and 0.06-0.48 apfu for elbaite. Regardless of the extent of $X$-site vacancies, $\mathrm{Na}$ is always greater than $\mathrm{Ca}$ in all tourmalines examined; most contain almost no $\mathrm{Ca}$ (Fig. 11). Most of the tourmalines in the SPG contain low $\mathrm{Mg} \leq 0.60 \mathrm{apfu}$, except for schorl and foitite which may have up to 1.44 apfu $\mathrm{Mg}$, and the occasional dravite with $>2.5$ apfu $\mathrm{Mg}$. Ti $(\leq 0.15$ apfu $)$ and $\mathrm{Zn}(\leq 0.21$ apfu $)$ are also low and only reach their maximum concentration in schorl from simple pegmatites. High $\mathrm{F}$ contents

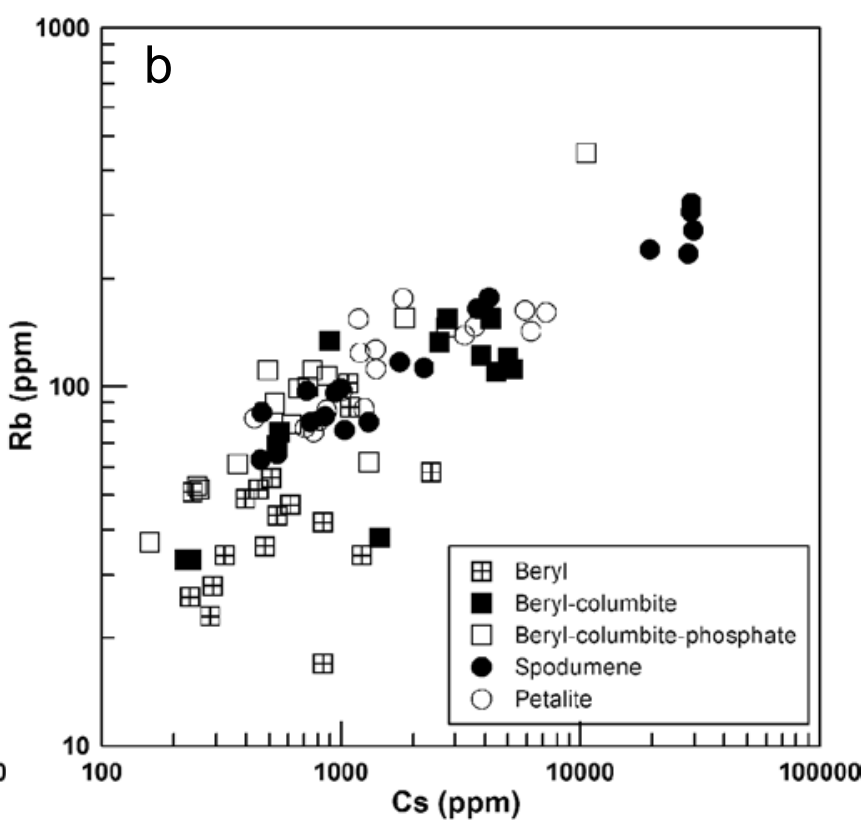

Fig. 10 Plot of $\mathrm{Na} / \mathrm{Li}$ (a) and $\mathrm{Rb}$ (b) vs. Cs for beryl from the Sebago Pegmatite Group. c - Columbite-group minerals plotted in the columbite quadrilateral $[\mathrm{Mn} /(\mathrm{Mn}+\mathrm{Fe})$ vs. Ta/(Ta $+\mathrm{Nb})]$. Dashed lines are boundaries of columbite-tantalite and tapiolite compositional gap Černý and Ercit (1989).

(0.90-1.11 apfu) and moderate Mn contents (0.33-0.45 apfu) are typical of elbaite in the $\mathrm{Li}$-enriched pegmatites of the SPG (Tab. 8).

The general crystallization sequence of tourmaline is consistent with that described by Selway (1999) and proceeds as follows: foitite $\rightarrow$ schorl $\rightarrow$ elbaite (Fig. 12). Black tourmaline that forms part of the garnet seam assemblage (e.g. Pulsifer and Mt. Mica pegmatites), or as the poikilitic grains making the texturally "spotted" aplite (e.g. Bennett and Westinghouse pegmatites) show compositions (schorl) that are similar to those from their wall zones despite having crystallized during a later stage of pegmatite consolidation. A thick band of black 
Tab. 7 Selected electron microprobe compositions of columbite-tantalite from the Sebago Pegmatite Group

\begin{tabular}{|c|c|c|c|c|c|c|c|c|c|c|}
\hline & 1 & 2 & 3 & 4 & 5 & 6 & 7 & 8 & 9 & 10 \\
\hline $\mathrm{WO}_{3}$ & 0.00 & 0.00 & 0.00 & 0.00 & 0.00 & 0.00 & 1.18 & 0.04 & 0.00 & 0.49 \\
\hline $\mathrm{Nb}_{2} \mathrm{O}_{5}$ & 69.36 & 63.72 & 66.47 & 58.49 & 7.29 & 46.37 & 66.62 & 27.71 & 65.19 & 66.91 \\
\hline $\mathrm{Ta}_{2} \mathrm{O}_{5}$ & 9.76 & 16.78 & 9.39 & 21.49 & 78.89 & 33.76 & 10.29 & 56.10 & 12.56 & 10.10 \\
\hline $\mathrm{TiO}_{2}$ & 0.17 & 0.12 & 1.26 & 0.50 & 0.00 & 1.11 & 0.60 & 0.11 & 1.08 & 1.05 \\
\hline $\mathrm{SnO}_{2}$ & 0.08 & 0.08 & 0.38 & 0.86 & 0.76 & 0.22 & 0.17 & 0.07 & 0.09 & 0.17 \\
\hline $\mathrm{Sc}_{2} \mathrm{O}_{3}$ & 0.00 & 0.00 & 0.00 & 0.00 & 0.00 & 0.00 & 0.10 & 0.03 & 0.00 & 0.15 \\
\hline $\mathrm{Fe}_{2} \mathrm{O}_{3}^{*}$ & 0.85 & 0.90 & 2.45 & 1.24 & 0.35 & 1.18 & 1.73 & 0.50 & 1.76 & 2.82 \\
\hline $\mathrm{FeO}$ & 10.70 & 5.64 & 13.19 & 6.10 & 0.08 & 14.08 & 7.97 & 0.24 & 12.89 & 10.59 \\
\hline $\mathrm{MnO}$ & 9.14 & 13.73 & 5.14 & 12.49 & 14.37 & 3.37 & 11.10 & 15.94 & 5.90 & 7.84 \\
\hline $\mathrm{MgO}$ & 0.00 & 0.00 & 0.02 & 0.00 & 0.00 & 0.03 & 0.09 & 0.02 & 0.02 & 0.04 \\
\hline $\mathrm{CaO}$ & 0.00 & 0.00 & 0.02 & 0.02 & 0.00 & 0.00 & 0.00 & 0.00 & 0.01 & 0.03 \\
\hline Total & 100.06 & 100.97 & 98.32 & 101.19 & 101.74 & 100.12 & 99.85 & 100.76 & 99.50 & 100.19 \\
\hline \multicolumn{11}{|c|}{ Number of cations on the basis of 24 oxygens } \\
\hline W & 0.000 & 0.000 & 0.000 & 0.000 & 0.000 & 0.000 & 0.072 & 0.003 & 0.000 & 0.029 \\
\hline $\mathrm{Nb}$ & 7.307 & 6.843 & 7.078 & 6.394 & 1.052 & 5.398 & 7.050 & 3.577 & 6.954 & 7.011 \\
\hline $\mathrm{Ta}$ & 0.618 & 1.084 & 0.602 & 1.413 & 6.854 & 2.364 & 0.655 & 4.356 & 0.806 & 0.637 \\
\hline $\mathrm{Ti}$ & 0.030 & 0.021 & 0.224 & 0.091 & 0.000 & 0.215 & 0.106 & 0.024 & 0.192 & 0.183 \\
\hline Sn & 0.007 & 0.008 & 0.036 & 0.083 & 0.096 & 0.022 & 0.016 & 0.008 & 0.008 & 0.016 \\
\hline $\mathrm{Sc}$ & 0.000 & 0.000 & 0.000 & 0.000 & 0.000 & 0.000 & 0.020 & 0.007 & 0.000 & 0.030 \\
\hline B-site sum & 7.962 & 7.956 & 7.940 & 7.981 & 8.002 & 7.999 & 7.919 & 7.975 & 7.960 & 7.906 \\
\hline $\mathrm{Fe}^{3+}$ & 0.149 & 0.161 & 0.434 & 0.225 & 0.084 & 0.229 & 0.305 & 0.108 & 0.312 & 0.492 \\
\hline $\mathrm{Fe}^{2+}$ & 2.084 & 1.121 & 2.596 & 1.233 & 0.022 & 3.032 & 1.561 & 0.056 & 2.544 & 2.053 \\
\hline $\mathrm{Mn}$ & 1.804 & 2.763 & 1.026 & 2.558 & 3.888 & 0.735 & 2.201 & 3.855 & 1.180 & 1.539 \\
\hline $\mathrm{Mg}$ & 0.000 & 0.000 & 0.008 & 0.000 & 0.000 & 0.012 & 0.031 & 0.009 & 0.008 & 0.014 \\
\hline $\mathrm{Ca}$ & 0.000 & 0.000 & 0.006 & 0.005 & 0.000 & 0.000 & 0.000 & 0.000 & 0.002 & 0.007 \\
\hline A-site sum & 4.037 & 4.045 & 4.070 & 4.021 & 3.994 & 4.008 & 4.098 & 4.028 & 4.046 & 4.105 \\
\hline Total & 11.999 & 12.001 & 12.010 & 12.002 & 11.996 & 12.007 & 12.017 & 12.003 & 12.006 & 12.011 \\
\hline $\mathrm{Mn} /(\mathrm{Mn}+\mathrm{Fe})$ & 0.45 & 0.68 & 0.25 & 0.64 & 0.97 & 0.18 & 0.54 & 0.96 & 0.29 & 0.38 \\
\hline $\mathrm{Ta} /(\mathrm{Ta}+\mathrm{Nb})$ & 0.08 & 0.14 & 0.08 & 0.18 & 0.87 & 0.30 & 0.09 & 0.55 & 0.10 & 0.08 \\
\hline
\end{tabular}

1 - Berry-Havey, 2 - Turner, 3 - GE, 4 - Westinghouse, 5 - Bennett, 6 - Heikkinen, 7 - BB \#7, 8 - Waisanen, 9 - Cole, 10 - Pingree.

* Calculated $\mathrm{Fe}_{2} \mathrm{O}_{3}$.

tourmaline that borders the spotted aplite body in the Bennett pegmatite was also shown to be schorl. Pink or green tourmalines that crystallized in miarolitic cavities of the Sebago pegmatites are always elbaite, and many have compositions that evolve towards rossmanite. On the other hand, dravite from the Songo Pond pegmatite primarily shows the $Y$-site substitution of Fe for $\mathrm{Mg}$ with compositions evolving towards schorl.

\subsubsection{Zr, P, Li and Cs phases}

Zircon is widespread, but uncommon in the Sebago pegmatites. All of the examined zircons were collected from beryl-columbite-phosphate, spodumene and petalite subtype pegmatites. Zircon crystals were typically $0.1-0.5 \mathrm{~mm}$ across, black to brownish in color with short prismatic morphology. BSE images show variable inter- nal structures that include largely metamict cores with unzoned, irregularly zoned or oscillatory zoned rims. The chemical composition of zircon shows low to moderate $\mathrm{Hf}$ contents with up to $5.3 \mathrm{wt} \% \mathrm{HfO}_{2}$; the range of $100 \mathrm{Hf} /(\mathrm{Hf}+\mathrm{Zr})$ values is $1.5-5.4$.

Fluorapatite is the most abundant and most widespread primary phosphate in the SPG. It occurs throughout both Li-poor and Li-rich pegmatites as light to dark green crystals, while dark blue, white, and purple fluorapatite is typically found in late-formed miarolitic cavities. Most of the examined fluorapatites are Mn-enriched, with up to 10.22 wt. \% MnO. Members of the triphylite-lithiophilite series are generally found in spodumene- and petalitebearing pegmatites. Chemical analyses of triphylitelithiophilite from the SPG have $\mathrm{Mn} /(\mathrm{Mn}+\mathrm{Fe})$ ratios of 0.40-0.97 (Moore 2000). Masses of snow-white montebrasite, up to $10 \mathrm{~cm}$ across, are also found predominantly 
Tab. 8 Selected electron microprobe compositions tourmaline from the Sebago Pegmatite Group

\begin{tabular}{|c|c|c|c|c|c|c|c|c|}
\hline & 1 & 2 & 3 & 4 & 5 & 6 & 7 & 8 \\
\hline $\mathrm{SiO}_{2}$ & 34.50 & 35.33 & 35.96 & 35.20 & 34.91 & 37.04 & 37.08 & 37.46 \\
\hline $\mathrm{TiO}_{2}$ & 0.27 & 0.21 & 0.12 & 0.23 & 0.06 & 0.02 & 0.11 & 0.00 \\
\hline $\mathrm{B}_{2} \mathrm{O}_{3}$ & 10.12 & 10.39 & 10.51 & 10.47 & 10.34 & 10.80 & 10.72 & 11.07 \\
\hline $\mathrm{Al}_{2} \mathrm{O}_{3}$ & 31.25 & 33.92 & 34.09 & 34.36 & 33.52 & 38.07 & 36.81 & 42.14 \\
\hline $\mathrm{FeO}$ & 15.03 & 13.71 & 11.35 & 11.80 & 15.11 & 3.75 & 6.47 & 0.05 \\
\hline $\mathrm{MgO}$ & 1.67 & 1.25 & 2.92 & 2.54 & 0.88 & 0.01 & 0.00 & 0.03 \\
\hline $\mathrm{CaO}$ & 0.04 & 0.06 & 0.08 & 0.13 & 0.07 & 0.08 & 0.19 & 0.26 \\
\hline $\mathrm{MnO}$ & 0.28 & 0.19 & 0.12 & 0.11 & 0.16 & 2.25 & 0.62 & 1.11 \\
\hline $\mathrm{ZnO}$ & 0.23 & 0.21 & 0.08 & 0.07 & 0.30 & 0.18 & 0.12 & 0.00 \\
\hline $\mathrm{Li}_{2} \mathrm{O}$ & 0.07 & 0.15 & 0.11 & 0.18 & 0.11 & 1.52 & 1.50 & 1.83 \\
\hline $\mathrm{Na}_{2} \mathrm{O}$ & 2.35 & 1.60 & 1.46 & 1.86 & 1.97 & 2.57 & 2.57 & 1.65 \\
\hline $\mathrm{K}_{2} \mathrm{O}$ & 0.00 & 0.02 & 0.01 & 0.06 & 0.05 & 0.03 & 0.02 & 0.00 \\
\hline $\mathrm{H}_{2} \mathrm{O}$ & 3.25 & 3.59 & 3.62 & 3.58 & 3.23 & 2.92 & 3.17 & 3.44 \\
\hline $\mathrm{F}$ & 0.50 & 0.00 & 0.00 & 0.07 & 0.71 & 1.07 & 1.11 & 0.80 \\
\hline Total & 99.56 & 100.63 & 100.43 & 100.66 & 101.42 & 100.94 & 100.50 & 99.84 \\
\hline $\mathrm{O}=\mathrm{F}$ & -0.21 & -0.00 & -0.00 & -0.03 & -0.30 & -0.72 & -0.47 & -0.34 \\
\hline Total & 99.35 & 100.63 & 100.43 & 100.63 & 101.12 & 100.22 & 100.03 & 99.50 \\
\hline \multicolumn{9}{|c|}{ Structural formula based on 31 anions $(\mathrm{O}, \mathrm{OH}, \mathrm{F})$} \\
\hline $\mathrm{Si}^{4+}$ & 5.928 & 5.908 & 5.949 & 5.842 & 5.870 & 5.961 & 6.010 & 5.883 \\
\hline $\mathrm{Al}^{3+}$ & 0.072 & 0.092 & 0.051 & 0.158 & 0.130 & 0.039 & 0.000 & 0.117 \\
\hline T-site sum & 6.000 & 6.000 & 6.000 & 6.000 & 6.000 & 6.000 & 6.010 & 6.000 \\
\hline$\overline{\mathrm{B}^{3+}}$ & 3.000 & 3.000 & 3.000 & 3.000 & 3.000 & 3.000 & 3.000 & 3.000 \\
\hline $\mathrm{Al}^{3+}$ & 6.000 & 6.000 & 6.000 & 6.000 & 6.000 & 6.000 & 6.000 & 6.000 \\
\hline Z-site sum & 6.000 & 6.000 & 6.000 & 6.000 & 6.000 & 6.000 & 6.000 & 6.000 \\
\hline$\overline{\mathrm{Al}^{3+}}$ & 0.256 & 0.593 & 0.595 & 0.562 & 0.512 & 1.181 & 1.032 & 1.683 \\
\hline $\mathrm{Ti}^{4+}$ & 0.035 & 0.026 & 0.015 & 0.029 & 0.008 & 0.002 & 0.013 & 0.000 \\
\hline $\mathrm{Mg}^{2+}$ & 0.428 & 0.312 & 0.720 & 0.628 & 0.221 & 0.002 & 0.000 & 0.007 \\
\hline $\mathrm{Mn}^{2+}$ & 0.041 & 0.027 & 0.017 & 0.015 & 0.023 & 0.307 & 0.085 & 0.148 \\
\hline $\mathrm{Fe}^{2+}$ & 2.160 & 1.917 & 1.570 & 1.638 & 2.125 & 0.505 & 0.877 & 0.007 \\
\hline $\mathrm{Zn}^{2+}$ & 0.029 & 0.026 & 0.010 & 0.009 & 0.037 & 0.021 & 0.014 & 0.000 \\
\hline $\mathrm{Li}^{+}$ & 0.051 & 0.099 & 0.073 & 0.119 & 0.075 & 0.982 & 0.978 & 1.156 \\
\hline Y-site sum & 3.000 & 3.000 & 3.000 & 3.000 & 3.000 & 3.000 & 3.000 & 3.000 \\
\hline $\mathrm{Ca}^{2+}$ & 0.007 & 0.011 & 0.014 & 0.023 & 0.013 & 0.014 & 0.033 & 0.044 \\
\hline $\mathrm{Na}^{+}$ & 0.783 & 0.519 & 0.468 & 0.598 & 0.642 & 0.802 & 0.808 & 0.502 \\
\hline $\mathrm{K}^{+}$ & 0.000 & 0.004 & 0.002 & 0.013 & 0.011 & 0.006 & 0.004 & 0.000 \\
\hline $\mathrm{X}$-site sum & 0.790 & 0.534 & 0.484 & 0.634 & 0.666 & 0.821 & 0.842 & 0.546 \\
\hline $\mathrm{OH}^{-}$ & 3.728 & 4.000 & 4.000 & 3.963 & 3.622 & 3.135 & 3.431 & 3.603 \\
\hline $\mathrm{F}^{-}$ & 0.272 & 0.000 & 0.000 & 0.037 & 0.378 & 0.865 & 0.569 & 0.397 \\
\hline
\end{tabular}

1 - Songo Pond, 2 - Green, 3 - Mt. Marie, 4 - Witt Hill, 5 - Maine Feldspar, 6 - Berry-Havey, 7 - Harvard, 8 - Bennett.

$\mathrm{B}_{2} \mathrm{O}_{3}, \mathrm{Li}_{2} \mathrm{O}$, and $\mathrm{H}_{2} \mathrm{O}$ for tourmaline calculated based on stoichiometry.

in Li-rich pegmatites, but may also occur in some berylcolumbite-phosphate subtype pegmatites. Negligible amounts of graftonite, $\left(\mathrm{Fe}^{2+}, \mathrm{Mn}, \mathrm{Ca}\right)_{3}\left(\mathrm{PO}_{4}\right)_{2}$, and triplite $\left(\mathrm{Mn}, \mathrm{Fe}^{2+}, \mathrm{Mg}, \mathrm{Ca}\right)_{2}\left(\mathrm{PO}_{4}\right)(\mathrm{F}, \mathrm{OH})$, occur locally within the Sebago pegmatites. The Tamminen and Waisenen pegmatites are the only localities known to contain graftonite. Glass and Fahey (1937) reported a manganoan graftonite with a $\mathrm{Mn} /(\mathrm{Mn}+\mathrm{Fe})$ ratio of 0.48 from the Tamminen locality. Large masses of primary triplite have been found at the Lord Hill pegmatite and have $\mathrm{Mn} /(\mathrm{Mn}+\mathrm{Fe})$ values of 0.74-0.77 (Johnson 1998).

Pollucite occurs rarely in only the most chemically evolved Sebago pegmatites (e.g. Bennett, General Electric, Emmons, Mt. Marie, Mt. Mica). It is found as anhedral masses near the core and is typically associated with quartz, albite, K-feldspar, spodumene, petalite and lepido- 
lite. Pollucite easily succumbs to alteration, often leaving a mass of clay as the only clue of its former presence (e.g, Bennett pegmatite). Primary pollucite from the SPG has an average $\mathrm{CRK}$ (where $\mathrm{CRK}=100(\mathrm{Cs}+\mathrm{Rb}+\mathrm{K}$ )/ $\Sigma$ cations and $\Sigma$ cations $=\mathrm{Li}+\mathrm{Na}+\mathrm{K}+\mathrm{Cs}+\mathrm{Rb}+\mathrm{Ca})$ of 76.9-87.3 and $\mathrm{Si} / \mathrm{Al}=2.31-2.56$ (Teertstra pers. comm.). End-member $\mathrm{CsAlSi}_{2} \mathrm{O}_{6}$ with $\mathrm{CRK}=99$, occurs locally as a product of low-temperature hydrothermal alteration of primary pollucite (Teertstra and Černý 1995).

\section{Discussion}

\subsection{Patterns of rare-element enrichment in the SPG}

Geochemical indicators, such as $\mathrm{K} / \mathrm{Rb}$ and $\mathrm{K} / \mathrm{Cs}$ in $\mathrm{K}$-feldspar and micas, $\mathrm{Nb} / \mathrm{Ta}$ in columbite group minerals, $\mathrm{Zr} / \mathrm{Hf}$ in zircon and $\mathrm{Fe} / \mathrm{Mn}$ in garnet, serve as important tools which, along with field relationships, have proven invaluable in establishing fractionation trends of rareelements in individual pegmatites and granite-pegmatite systems (e.g., Trueman and Černý 1982; Černý et al. 1985; Černý 1991) and developing models for the petrogenesis and evolution of granite-pegmatite systems (e.g., Legg and Namateba 1982; Shearer et al. 1985; Černý 1991; Jolliff et al. 1992; Alfonso et al. 2003). Fertile granites that are parental to mineralized pegmatites often exhibit gradual changes in fractionation indicators and levels of lithophile rare-elements enrichment with progressive evolution of its pegmatite progeny (Černý and Meintzer 1988).

As reflected in their accessory mineralogy and trace element chemistry of K-feldspar and muscovite, the overall geochemical signature of the SPG can be characterized as generally peraluminous with considerable enrichment in $\mathrm{Be}, \mathrm{Nb}>\mathrm{Ta}, \mathrm{P}, \mathrm{Li}, \mathrm{Cs}$ and $\mathrm{B}$ with only modest enrichment in $\mathrm{Rb}, \mathrm{Sn}$ and $\mathrm{F}$. The mineral assemblages and chemical data indicate that many of the Sebago pegmatites are moderately to highly fractionated. Fractionation of $\mathrm{Fe}-\mathrm{Mn}$ in garnet, $\mathrm{Nb}-\mathrm{Ta}$ oxide minerals, and phosphates proceeds towards $\mathrm{Mn}$ enrichment as shown by the presence of spessartine, manganoan fluorapatite, lithiophilite, and manganocolumbite-manganotantalite. Extreme Mn enrichment is typical of lepidolite-bearing units rich in fluorine, thus the occurrence of Mn-dominant phases strongly suggests that the pegmatite melts were substantially enriched in F for at least a part of their crystallization history. Although many of the highly fractionated pegmatites are apparently enriched in F, they do not compare with the extreme level of $\mathrm{F}$ enrichment present within the Lord Hill pegmatite.

The degree of $\mathrm{Nb}-\mathrm{Ta}$ fractionation within the SPG is generally moderate as shown by the predominance of columbite over tantalite in most pegmatites. Only the
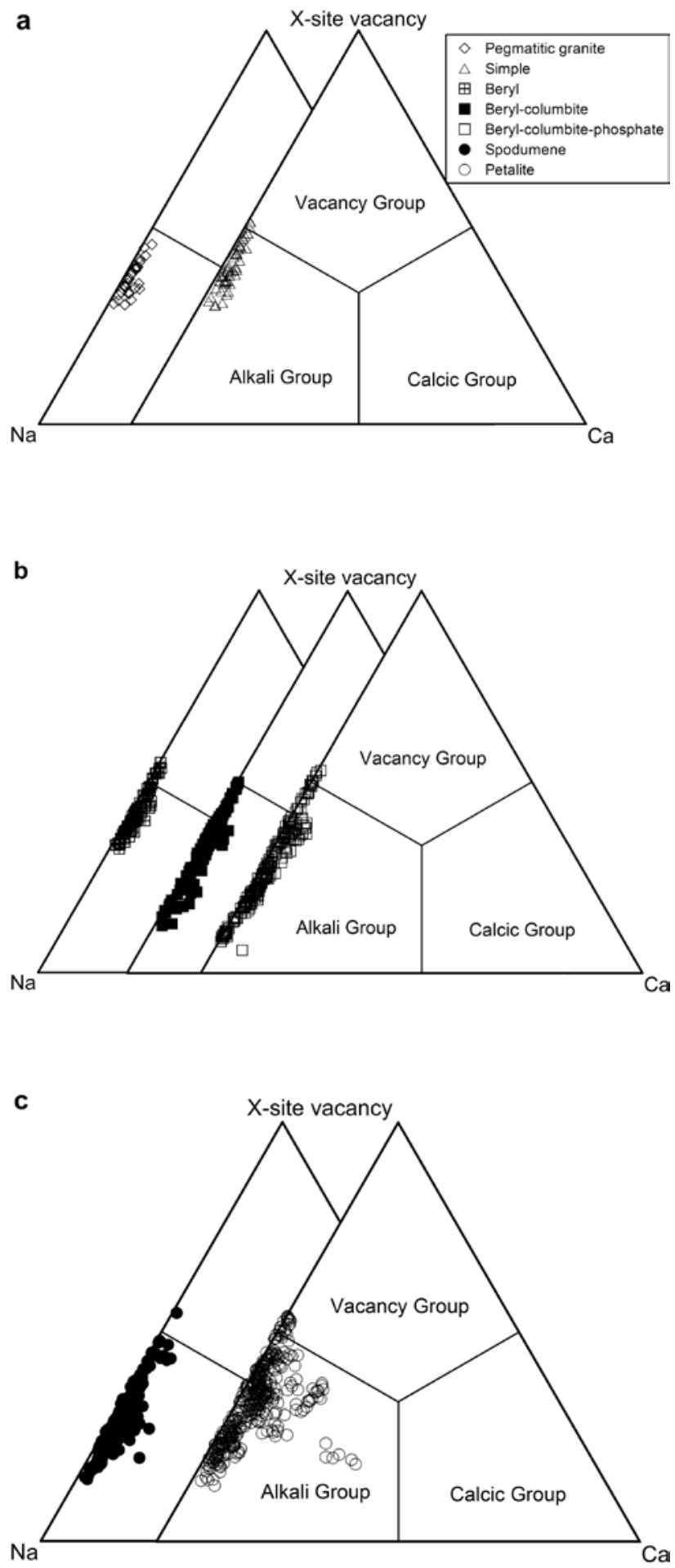

Fig. 11 Tourmaline compositions from Sebago Pegmatite Group plotted in the $\mathrm{Na}-\mathrm{Ca}$-vacancy ternary diagram.

most evolved pegmatites show significant Ta enrichment whereby manganotantalite occurs as an abundant phase. Columbite-group minerals crystallized from $\mathrm{F}$-enriched melts display distinctive curved fractionation trends 

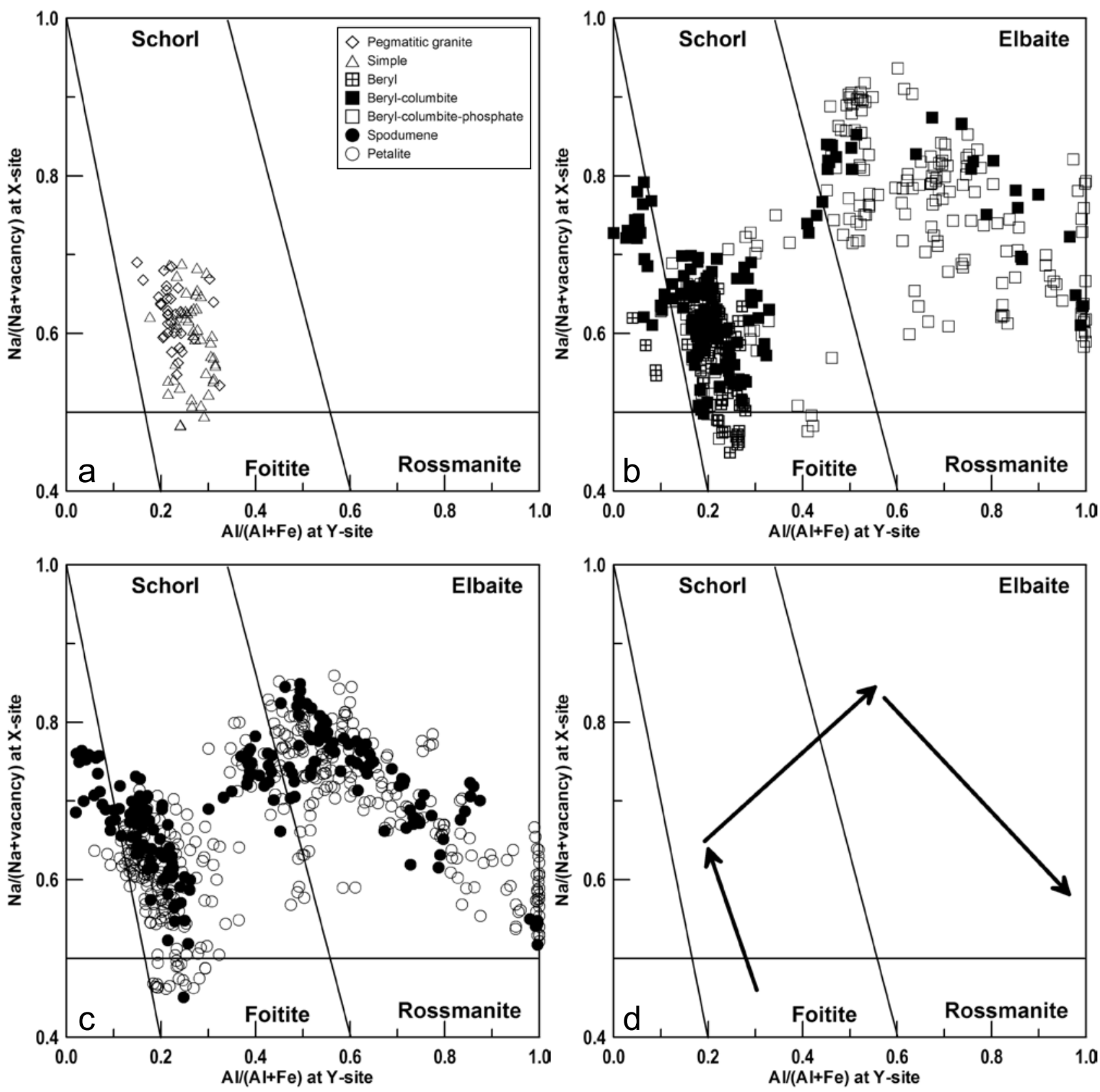

Fig. 12 Tourmaline compositions plotted in the $\mathrm{Na} /(\mathrm{Na}+$ vacancy) at $\mathrm{X}$-site vs. $\mathrm{Al} /(\mathrm{Al}+\mathrm{Fe})$ at the $\mathrm{Y}$-site for: pegmatitic granites and simple pegmatites (a), Be-rich pegmatites (b), and Li-rich pegmatites (c). d - General crystallization sequence of tourmaline for the Sebago Pegmatite Group. All diagrams modified after Selway (1999).

characterized by the initial crystallization of $\mathrm{Mn}-\mathrm{Nb}$ dominant phases with extremely low Ta contents and subsequently evolving to $\mathrm{Mn}-\mathrm{Ta}$ dominant members with very little $\mathrm{Nb}$ (e.g., Černý 1989). This fractionation trend is clearly observed in columbite-group minerals from a number of pegmatites in the SPG. With the exception of the Lord Hill pegmatite, columbite from the western part of the field show a fairly restricted level of Mn fractionation compared to the rest of the SPG.
Phosphorus mineralization is prevalent throughout the SPG as fluorapatite, but the most evolved pegmatites also contain primary Li-phosphates. Triplite is found in small quantities in a few pegmatites in the SPG, where its presence is largely the result of secondary alteration of lithiophilite and amblygonite-montebrasite. By comparison, primary triplite at Lord Hill suggests that, during its crystallization history, the pegmatite melt was saturated in $\mathrm{P}$ and $\mathrm{F}$. 
The presence of Li-alumosilicates, Li-phosphates and pollucite strongly supports at least moderate levels of $\mathrm{Li}$ and Cs fractionation within the SPG. The pegmatites along the northwestern margin of the SMD do not attain significant levels of $\mathrm{Li}$ and $\mathrm{Cs}$ enrichment relative to the remainder of the pegmatite population. Boron activity was high in the pegmatite melts as evidenced by ubiquitous tourmaline crystallization in many of the pegmatites and pegmatitic leucogranites. The level of $\mathrm{F}$ enrichment is low to moderate for much of the SPG, although high F manifests itself as F-rich topaz ( $\mathrm{F}=13$ and 19 wt. \%; Francis and Pittman 1995; Johnson 1998) and triplitebearing assemblages in a few pegmatites.

\subsection{The relation between the Sebago Pluton, SMD and the SPG}

The Sebago pegmatites represent a diverse group of dikes characterized by barren pegmatites transitional to $\mathrm{Be}$ pegmatites with subordinate Ta and $\mathrm{P}$ mineralization, and complex Li-enriched pegmatites that host spodumene or petalite. Wise and Francis (1992) suggested that the SPG constitutes a regionally zoned pegmatite population around the apparently parental "Sebago Batholith", however our fieldwork does not support their observations. The majority of pegmatites of the SPG intrude metasedimentary rocks of the CMB along the northern margins of the SMD. Along the northwestern margin of the SMD, the pegmatites are generally of the simple to slightly Be-enriched type; whereas pegmatites hosting Li mineralization are concentrated along the northeastern margin. Generally the SPG can be categorized as belonging to the rare-element class of LCT pegmatites of Černý and Ercit (2005) which presumably are related to a fertile $S$-type granite.

A small cluster of pegmatites within the northwestern part of the SPG exhibits chemical and mineralogical features more akin to the NYF geochemical family of granitic pegmatites that are typically affiliated with $A$-type granites generated in late-tectonic to anorogenic environments (Černý and Ercit 2005). The Lord Hill pegmatite, for example, contains topaz, fluorite, phenakite, and triplite. On the other hand, the Deer Hill, Intergalactic and Colton Hill pegmatites uniquely host amethyst which is generally absent in LCT pegmatite fields worldwide and considered by Brown (1999) to be representative of NYF family pegmatites. Differences between these pegmatites and the rest of the SPG may be attributed to different degrees of fractionation of a common parental melt, local contamination of pegmatite melts or derivation from a completely different source.

Our field observations indicate that many of the same textural features documented from worldwide fertile granites that are considered to be parental to populations of LCT rare-element granitic pegmatites (e.g., Yel- lowknife field, Northwest Territories, Canada, Meintzer et al. 1984; Greer Lake, Manitoba, Černý et al. 1981, 2005; Harney Peak granite, South Dakota, Shearer et al. 1987; Albuquerque Batholith, Spain, London et al. 1999; Kymi stock, Finland, Haapala and Lukkari 2005) have been identified in pegmatitic leucogranites of the Sebago area. Field investigations of these granites and pegmatites indicate that the fertile granite textural facies of Černý and Meintzer (1988) are prominently developed within small stocks of pegmatitic leucogranites that are best exposed within the metasedimentary rocks of the SMD and CMB along their northeastern contact. We also observed similar fluorapatite + albite-bearing units, aplitic pods with poikilitic schorl, and discontinuous bands of garnet in both the pegmatitic leucogranites and some of the neighboring pegmatite bodies (e.g., Bennett, Westinghouse, Pulsifer) which may signify a genetic connection. This, plus the close proximity of pegmatitic leucogranites to the SPG, provides additional evidence which supports these granites as being the likely source of the pegmatite population.

Outcrops of granite within the SMD may contain small, localized veins of texturally and mineralogically simple pegmatites. However these outcrops do not transition into pegmatitic textures and in no way resemble the features of the pegmatitic leucogranites observed in the outer margins of the SMD. This evidence implies, but does not confirm, that the two granite types are unrelated. Furthermore, the works of Tomascak et al. (1996b) and Solar and Tomascak (2009) do not indicate any direct relationship between granites of the Sebago Pluton and granites of the SMD.

The relationship between the Sebago Pluton, the SMD granites and the SPG remains unclear and requires further investigation. The composition of the main and accessory minerals indicates that the pegmatitic leucogranites are direct precursors to the majority of pegmatites of the SPG. Geochemical data also suggest that the pegmatites of the western portion of the SPG may be different from the rest of the pegmatite population. The unique mineralogy and geochemistry of the Lord Hill and amethyst-bearing pegmatites of the western part of the SPG implies that they could have originated from $A$ type granitic magmas in contrast to other pegmatites of the SPG which apparently evolved from $S$-type granitic magmas. However, anorogenic magmatism has not been documented in the western part of the pegmatite group and the nearest $A$-type granite occurs as part of the White Mountain Batholith located west of the SPG in New Hampshire. Additional investigation of the western SPG pegmatites and granites from the SMD and the White Mountain Batholith is needed in order to gain a better understanding of the origin and evolution of this part of the Sebago pegmatite population. 
Acknowledgements. The authors wish to thank P. Uher and an anonymous reviewer for critical review of the manuscript as well as careful editing by M. Novák and V. Janoušek. The authors gratefully acknowledge the cooperation and assistance of the many miners and landowners who provided numerous specimens for study and unlimited access to pegmatites and granite outcrops. Thanks are also extended to the Maine Geological Survey for their support and to the many assistants who aided the authors in the field. Special thanks are due to Al Falster for his contributions to the $\mathrm{Li}$ analysis of micas and beryl. Funding for this project was provided in part from the Smithsonian Institution's Sprague Endowment.

\section{References}

Alfonso P, Melgarejo JC, Yusta I, Velasco F (2003) Geochemistry of feldspars and muscovite in granitic pegmatite from the Cap de Creus field, Catalonia, Spain. Canad Mineral 41: 103-116

Anders E, Grevesse N (1989) Abundances of the elements: meteoritic and solar. Geochim Cosmochim Acta 53: 197-214

Barton WR, GolDSmith CE (1968) New England beryllium investigations. U.S. Bureau of Mines Report Investigations 7070, pp 1-177

BASTIN ES (1911) Geology of the pegmatites and associated rocks of Maine. US Geol Survey Bull 445: 1-152

BATCHELOR R, BOWDEN P (1985) Petrogenetic interpretation of granitic rock series using multicationic parameters. Chem Geol 48: 43-55

Behn MD, Eusden JD, JR., NotTe JA, III (1998) A threedimensional gravity model of the southern contact of the Sebago Pluton, Maine. Can J Earth Sci 35: 649-656

BRown CD (1999) Mineralogy of NYF granitic pegmatites. Canad Mineral 37: 848-849

Brown M, Solar GS (1998) Shear-zone systems and melts: feedback relations and self-organization in orogenic belts. J Struct Geol 20: 211-227

Cameron EN, Larabee DM, McNair AH, Page JJ, StewART GW, Shainin VE (1954). Pegmatite investigations 1942-1945, New England. US Geol Surv Prof Paper 225: pp 1-352

CARNESE MJ (1983) Gravity studies of intrusive rocks in West Central Maine. Unpublished MSci. thesis, Univ. New Hampshire, Durham, N.H., pp 1-97

CREASY JW (1979) Reconnaissance bedrock geology of the Poland Quadrangle, Maine. Maine Geological Survey, Dept. of Conservation, Open File Report, pp 79-15

ČERNÝ P (1975) Alkali variations in pegmatitic beryl and their petrogenetic implications. Neu Jb Mineral, Abh 123: $198-212$
ČERnÝ P (1989) Characteristics of pegmatite deposits of tantalum. In: Möller P, Černý P, SAupe F (eds) Lanthanides, Tantalum and Niobium. Springer-Verlag, Berlin, pp 195-239

ČERNÝ P (1991) Rare-element granitic pegmatites, Part 1: anatomy and internal evolution of pegmatite deposits. Geosci Can 18: 49-67

ČERNÝ P, ERCIT TS (1989) Mineralogy of niobium and tantalum: crystal chemical relationships, paragenetic aspects and their economic implications. In: Möller P, ČERNÝ P, SAUPE F (eds) Lanthanides, Tantalum and Niobium. Springer-Verlag, Berlin, pp 27-79

ČERNÝ P, ERCIT TS (2005) The classification of granitic pegmatites revisited. Canad Mineral 43: 2005-2026

Černý P, Meintzer RE (1988) Fertile granites in the Archaean and Proterozoic fields of rare-element pegmatites: crustal environment, geochemistry and petrogenetic relationships, In: TAYLOR RP, STRONG DF (eds) Recent Advances in the Geology of Granite-Related Mineral Deposits. Canadian Institute of Mining and Metallurgy, Special Volume 39: 170-207

Černý P, Meintzer RE, Anderson AJ (1985) Extreme fractionation in rare-element granitic pegmatites: selected examples of data and mechanisms. Canad Mineral 23: 381-421

Černý P, Trueman Dl, Ziehlke DV, Goad Be, Paul BJ (1981) The Cat Lake-Winnipeg River and the Wekusko Lake pegmatite fields, Manitoba. Manitoba Mineral Resources Division, Economic Geology Report ER80-1, pp 1-216

Černý P, Masau M, Goad BE, Ferreira K (2005) The Greer Lake leucogranite, Manitoba, and the origin of lepidolitesubtype granitic pegmatites. Lithos 80: 305-321

Dorais MJ, Paige ML (2000) Regional geochemical and isotopic variations of northern New England plutons: implications for magma sources and for Grenville and Avalon basement-terrane boundaries. Geol Soc Am Bull 112: 900-914

Francis CA, PitTMan LC (1995) The occurrence of topaz in northern New England pegmatites. Mineral Rec 26: 64

FrANCIS CA, WISE MA, ČERNÝ P (1991) Geochemical evolution of Nb-, Ta- and Sn-bearing minerals in rare-element granitic pegmatites of southwestern Maine. Geol Soc Am Abstr Programs 23: 388

Glass JJ, FAHEY JJ (1937) Graftonite from Greenwood, Maine. Amer Miner 22: 1035-1039

Guidotti CV, Gibson D, Lux DR, De Yoreo JJ, Cheney JT (1986) Carboniferous metamorphism on the north upper side of the Sebago Batholith. In: Newberg DW (ed) New England Intercollegiate Geological Conference Guidebook for Field Trips in Southwestern Maine. Bates College, Lewiston, pp 306-341

HaApala I, LukKari S (2005) Petrological and geochemical evolution of the Kymi stock, a topaz granite cupola 
within the Wiborg rapakivi batholith, Finland. Lithos 80: $347-362$

HAYWARD J (1989) Implications of the Rb-Sr and O isotopic systematics and geochemistry of some two-mica granites in northern New England. In: TUCKeR RD, MARVINNEY RG (eds) Studies in Maine Geology, Vol. 3, Maine Geological Survey, Augusta, pp 53-66

Hodge DS, Abbey DA, Harkin MA, Patterson JL, Ring MJ, SwEeney JF (1982). Gravity studies of subsurface mass distributions of granitic rocks in Maine and New Hampshire. Amer J Sci 282: 1289-1324

Holdaway MJ, Dutrow BL, Hinton RW (1988) Devonian and Carboniferous metamorphism in west-central Maine: the muscovite-almandine geobarometer and the staurolite problem revisited. Amer Miner 73: 20-47

IRVINE TN, BARAGAR WRA (1971) A guide to the chemical classification of the common volcanic rocks. Canad J Earth Sci 8: 523-548

Johnson RG (1998) Mineralogy and Geochemistry of the Lord Hill Pegmatite. Unpublished MSci. thesis, University of New Orleans, New Orleans, Louisiana, pp $1-127$

Jolliff BL, Papike JJ, Shearer CK (1992) Petrogenetic relationships between pegmatite and granite based on geochemistry of muscovite in pegmatite wall zones, Black Hills, South Dakota, USA. Geochim Cosmochim Acta 56: 1915-1939

LANDES KK (1925) The paragenesis of the granite pegmatites of central Maine. Amer Miner 10: 355-411.

Legg CA, Namateba C (1982) Regional zoning of tintantalum-niobium pegmatites in the Musuku area, Southern province, Zambia. In: Evans AM (ed) Metallization Associated with Acid Magmatism. John Wiley and Sons, Chichester, pp 181-190

LEvinson AA (1953) Studies in the mica group; relationship between polymorphism and composition in the muscovite-lepidolite system. Amer Miner 38: 88-107

LoNDON D (1984) Experimental phase equilibria in the system $\mathrm{LiAlSiO}_{4}-\mathrm{SiO}_{2}-\mathrm{H}_{2} \mathrm{O}$ : a petrogenetic grid for lithium-rich pegmatites. Amer Miner 69: 995-1004

London D, Wolf MB, Morgan VI GB, Garrido MG (1999). Experimental silicate-phosphate equilibria in peraluminous granitic magma, with a case study of the Albuquerque Batholith at Tres Arroyos, Badajoz, Spain. J Petrol 40: 215-240

Maniar PD, Piccoli PM (1989) Tectonic discrimination of granitoids. Geol Soc Am Bull 101: 635-643

Meintzer RE, Wise MA, ČernÝ P (1984) Distribution and structural setting of fertile granites and related pegmatites in the Yellowknife pegmatite field, District of Mackenzie. In: Current Research, Part A. Geological Survey of Canada, Paper 84-1A, 373-381

Moore PB (2000) Analyses of primary phosphates from pegmatites in Maine and other localities. In: KING VT (ed) Mineralogy of Maine: Volume 2 - Mining History, Gems and Geology, Maine Geological Survey, Augusta, pp 333-336

Neumann GL (1952) Bumpus pegmatite deposit, Oxford County, Maine. US Bureau Mines, Report of Investigations 4862: pp 1-15

O'CONNOR AC (1965) A classification for quartz-rich igneous rocks based on feldspar ratios. US Geol Surv Prof Paper 525B: 79-84

Osberg PH, Hussey AM II, Boone GM (1985) Bedrock geologic map of Maine. Maine Geological Survey, 1:500,000-scale map

Pearce JA, Harris NBW, Tindle AG (1984) Trace element discrimination diagrams for the tectonic interpretation of granitic rocks. J Petrol 25: 956-983

RAND JR (1957) Maine pegmatite mines and prospects and associated minerals. Maine Geological Survey, Minerals Resources Index. 3: pp 1-43

Selway JB (1999) Compositional Evolution of Tourmaline in Granitic Pegmatites. Unpublished Ph.D. thesis. University of Manitoba, Winnipeg, Canada, pp 1-363

Shearer CK, Papike JJ, Laul JC (1985) Chemistry of potassium feldspars from three zoned pegmatites, Black Hills, South Dakota: implications concerning pegmatite evolution. Geochim Cosmochim Acta 49: 663-673

Shearer CK, PapiKe JJ, Laul JC (1987) Mineralogical and chemical evolution of a rare-element granite-pegmatite system: Harney Peak granite, Black Hills, South Dakota. Geochim Cosmochim Acta 51: 473-486

Simmons WB, Foord EE, Falster AU, King VT (1995) Evidence for an anatectic origin of granitic pegmatites, western Maine, USA. Geol Soc Amer Abstr Programs 27: 411

Simmons WB, Laurs BM, Falster AU, Koivula JI, WebBER KL (2005) Mt. Mica: a renaissance in Maine‘s gem tourmaline production. Gems Gemol 41: 150-163

Solar GS, Brown M (2001) Petrogenesis of migmatites in Maine, USA: possible source of peraluminous leucogranite in plutons. J Petrol 42: 789-823

Solar GS, TomascaK PB (2001) Is there a relation between transpressive deformation and pluton emplacement in southern Maine? 2001 Annual Meeting of Northeastern Section, Geol Soc Amer Abstr Programs 33, pp A6

Solar GS, Tomascak PB (2009) The Sebago Pluton and the Sebago Migmatite Domain, southern Maine; results from new studies. 2009 Annual Meeting of Northeastern Section, Geol Soc Amer, Field Trip 2, pp 1-24

Streckeisen AL (1973) Plutonic rocks: classification and nomenclature recommended by the IUGS subcommission of the systematics of igneous rocks. Geotimes 18: 26-30

Teertstra DK, ČERnÝ P (1995) First natural occurrences of end-member pollucite: a product of low-temperature reequilibaration. Canad Mineral 7: 1137-1148 
Thomson JA, Guidotti CV (1989) Carboniferous Barrovian metamorphism in southern Maine. In: TUCKER RD, MARVINNEY RG (eds) Studies in Maine Geology, Vol. 1. Maine Geological Survey, Augusta, pp 35-51

Thompson WB, Wintringham NA, King VT (2000) Maine mineral locality index. In: KING VT (ed) Mineralogy of Maine: Volume 2 - Mining History, Gems and Geology, Maine Geological Survey, Augusta, pp 355-426

TOMASCAK PB (1991) Granites and Rare-element Pegmatites of the Aylmer Lake Pegmatite Field, Slave Structural Province, N.W.T.: Petrochemistry, Mineralogy and Exploration Guidelines. Unpublished MSci. thesis, University of Manitoba, Winnipeg, Canada, pp 1-215

Tomascak PB, Krogstad EJ, Walker RJ (1996a) U-Pb monazite geochronology of granitic rocks from Maine: implications for late Paleozoic tectonics in the Northern Appalachians. J Geol 104: 185-195

Tomascak PB, Krogstad EJ, WaLker RJ (1996b) Nature of the crust in Maine, USA: evidence from the Sebago Batholith. Contrib Mineral Petrol 125: 45-59
TRUEMAN DL, ČERnÝ P (1982). Exploration for rare-element granitic pegmatites. In: ČERNÝ P (ed) Granitic Pegmatites in Science and Industry. Mineral Assoc Canad Short Course Handbook 8: pp 463-493

Wise MA (1994) Phosphorus in pegmatitic garnets - examples from Maine. International Mineralogical Association, $16^{\text {th }}$ General Meeting, Pisa (Italy) Abstracts, pp 441

WISE MA (1995) Trace element chemistry of lithium-rich micas from rare-element granitic pegmatites. Mineral Petrol 55: 203-215

Wise MA, Francis CA (1992) Distribution, classification and geological setting of granitic pegmatites in Maine. Northeast Geol 14: 82-93

Wise MA, Rose TR (2000) The Bennett pegmatite, Oxford Maine: In: KING VT (ed) Mineralogy of Maine: Volume 2 - Mining History, Gems and Geology, Maine Geological Survey, Augusta, pp 323-332

WoODARD HH (1951) The geology and paragenesis of the Lord Hill pegmatite, Stoneham, Maine. Amer Miner 36: $869-883$ 